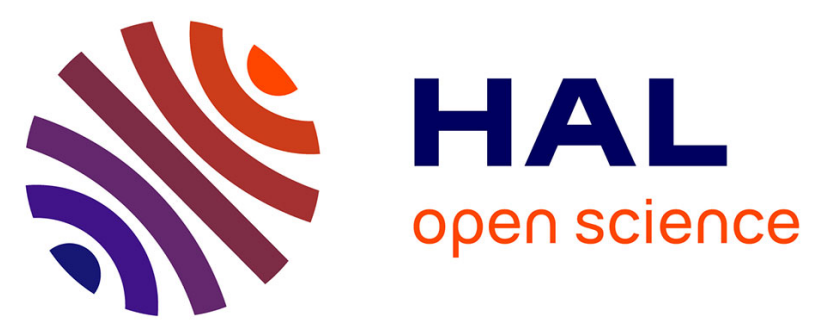

\title{
Historical biogeography of the highly diverse brown seaweed Lobophora (Dictyotales, Phaeophyceae)
}

Christophe Vieira, Olga Camacho, Zhongmin Sun, Suzanne Fredericq, Frederik Leliaert, Claude Payri, Olivier de Clerck

\section{- To cite this version:}

Christophe Vieira, Olga Camacho, Zhongmin Sun, Suzanne Fredericq, Frederik Leliaert, et al.. Historical biogeography of the highly diverse brown seaweed Lobophora (Dictyotales, Phaeophyceae). Molecular Phylogenetics and Evolution, 2017, 110, pp.81 - 92. 10.1016/j.ympev.2017.03.007 . hal01535635

\section{HAL Id: hal-01535635 \\ https://hal.sorbonne-universite.fr/hal-01535635}

Submitted on 9 Jun 2017

HAL is a multi-disciplinary open access archive for the deposit and dissemination of scientific research documents, whether they are published or not. The documents may come from teaching and research institutions in France or abroad, or from public or private research centers.
L'archive ouverte pluridisciplinaire HAL, est destinée au dépôt et à la diffusion de documents scientifiques de niveau recherche, publiés ou non, émanant des établissements d'enseignement et de recherche français ou étrangers, des laboratoires publics ou privés. 
1 Historical biogeography of the highly diverse brown seaweed Lobophora

2 (Dictyotales, Phaeophyceae)

3

4

Christophe Vieira ${ }^{\mathrm{a}, \mathrm{b}, \mathrm{c} *}$, Olga Camacho ${ }^{\mathrm{d}}$, Zhongmin Sun $^{\mathrm{e}}$, Suzanne Fredericq ${ }^{\mathrm{d}}$, Frederik Leliaert $^{\mathrm{b}, \mathrm{f}}$, Claude Payri ${ }^{\mathrm{a}}$, Olivier De Clerck ${ }^{\mathrm{b}}$

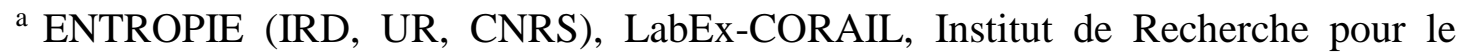
Développement, B.P. A5, 98848, Nouméa Cedex, Nouvelle-Calédonie, France

${ }^{\mathrm{b}}$ Phycology Research Group and Center for Molecular Phylogenetics and Evolution, Ghent University, Gent, Belgium, B-9000

${ }^{\mathrm{c}}$ Sorbonne Universités, UPMC Univ Paris 06, IFD, PARIS, France, F75252

${ }^{\mathrm{d}}$ Department of Biology, University of Louisiana at Lafayette, Lafayette LA 705043602, USA

${ }^{\mathrm{e}}$ Institute of Oceanology, Chinese Academy of Sciences, Department of Marine Organism Taxonomy and Phylogeny

${ }^{\mathrm{f}}$ Botanic Garden Meise, 1860 Meise, Belgium

* Correspondence: Christophe Vieira, E-mail: cvcarp@gmail.com

\section{Submission to MPE as an Original Article}

Running title: Present and historical biogeography of Lobophora.

\section{Highlights}

- Lobophora global species diversity is estimated to be $>100$ species.

- We provide a multi-locus time-calibrated molecular phylogeny for Lobophora.

- Ancestral range reconstruction suggests Lobophora originated in the Tethys Sea.

- Lobophora molecular phylogeny revealed an upper Cretaceous origin.

- Within marine realms speciation and founder events were significant processes.

This research did not receive any specific grant from funding agencies in the public, commercial, or not-for-profit sectors. 


\section{ABSTRACT}

The tropical to warm-temperate marine brown macroalgal genus Lobophora

(Dictyotales, Phaeophyceae) recently drew attention because of its striking regional diversity. In this study we reassess Lobophora global species diversity, and species distributions, and explore how historical factors have shaped current diversity patterns. We applied a series of algorithmic species delineation techniques on a global mitochondrial cox3 dataset of 598 specimens, resulting in an estimation of 98 to 121 species. This diversity by far exceeds traditional diversity estimates based on morphological data. A multi-locus time-calibrated species phylogeny using a relaxed molecular clock, along with DNA-confirmed species distribution data was used to analyse ancestral area distributions, dispersal-vicariance-founder events, and temporal patterns of diversification under different biogeographical models. The origin of Lobophora was estimated in the Upper Cretaceous (-75 to $-60 \mathrm{MY}$ ), followed by gradual diversification until present. While most speciation events were inferred within marine realms, founder events also played a non-negligible role in Lobophora diversification. The Central Indo-Pacific showed the highest species diversity as a result of higher speciation events in this region. Most Lobophora species have small ranges limited to marine realms. Lobophora probably originated in the Tethys Sea and dispersed repeatedly in the Atlantic (including the Gulf of Mexico) and Pacific Oceans. The formation of the major historical marine barriers (Terminal Tethyan event, Isthmus of Panama, Benguela upwelling) did not act as important vicariance events. Long-distance dispersal presumably represented an important mode of speciation over evolutionary time-scales. The limited geographical ranges of most Lobophora species, however, vouch for the rarity of such events. 
59 Keywords Algorithmic species estimation; ancestral area reconstruction; historical 60 biogeography; Lobophora; molecular dating. 


\section{Introduction}

A good understanding of species diversity is essential for addressing biogeographical questions. Recent studies addressing the magnitude of eukaryotic diversity of terrestrial and marine systems (Appeltans et al., 2012; Costello et al., 2013; Mora et al., 2011; Scheffers et al., 2012; Sweetlove, 2011) have highlighted the large uncertainty in global species diversity, with global species diversity estimates ranging between 2 and 50 million species. In addition, the application of DNA markers to delineate species (DNA taxonomy (DNA taxonomy; Blaxter, 2004) disclosed levels of cryptic species diversity, which in many cases outnumber traditionally recognized species by a factor 10 (Adams et al., 2014). Failure to recognize cryptic species not only results in underestimation of species diversity, but may also have significant consequences for the interpretation of macroevolutionary patterns and for species conservation (Agapow et al., 2004; Bickford et al., 2007). Recent estimates of global biodiversity, however, did not take into account the magnitude of cryptic species (but see Appeltans et al., 2012), which is likely to be common in many organismal groups (Adams et al., 2014; Pfenninger and Schwenk, 2007). Algae represents a group for which the magnitude of diversity remains highly uncertain (De Clerck et al., 2013; Guiry, 2012). Several regional case studies demonstrated that algal species diversity could be up-scaled with one or two orders of magnitude (e.g. Evans et al., 2007; Leliaert et al., 2014; Payo et al., 2013; Saunders, 2008; Stiller and Waaland, 1993), recognizing the high level of cryptic species in this group (but several studies did not unveil a lot of cryptic species).

3 Next to the uncertainty on diversity estimates, it is unclear how local diversity estimates translate into global diversity. Estimations of the global diversity of any given group require insights in the geographical structuring of species diversity. High 

local diversity may not necessarily translate into high global diversity, because of broad geographic ranges and/or the paucity of species diversity in other regions. Conversely, narrow species ranges may result in relatively low species diversity at a local scale, but high global diversity.

While in general diversity is lower in the sea than on land, marine species diversity in some groups and areas can be high (Appeltans et al., 2012; De Vargas et al., 2015; Grosberg et al., 2012; May and Godfrey, 1994; Vermeij and Grosberg, 2010). This high species diversity in the marine environment raises evolutionary questions related to the drivers and mechanisms of evolutionary diversification. Geographic isolation is the traditional explanation for diversification, but there is growing consensus that sympatric adaptive diversification may be an important source of diversity in the marine environment (Bowen et al., 2013; Schluter, 1996, 2001). Opportunities for allopatric speciation are reduced in the ocean since there are few physical barriers, and dispersal may be extensive (Bowen et al., 2013). Although certainly true for many fishes and invertebrates with pelagic larval stages that have high dispersal potential (Kinlan and Gaines, 2003), long-distance dispersal is rarer in marine macroalgae as propagules have been shown to have limited dispersal capabilities (Kinlan and Gaines, 2003; Norton, 1992; Santelices, 1990). There are, however, exceptions of macroalgal species with high dispersal capacity and wide geographical ranges, including Macrocystis pyrifera (Macaya and Zuccarello, 2010), Boodlea (Leliaert et al., 2009), Colpomenia (Lee et al., 2014; Lee et al., 2013), Ulva (Kirkendale et al., 2013), Adenocystis utricularis and Bostrychia intricata (Fraser et al., 2013). The relative scarcity of cosmopolitan marine macroalgal species, confirmed by molecular methods, is evidence that long-distance dispersal is not as common as in other groups (e.g. with pelagic larval stages). Indeed, many alleged 
111 cosmopolitan species have eventually been shown to represent a complex of 112 genetically distinct species with more restricted distributions (De Clerck et al., 2005;

113 Leliaert et al., 2009; Tronholm et al., 2012; Zuccarello and West, 2003). The strength 114 and spatial extent of gene flow is expected to be an important determinant of the 115 spatial scale at which genetic divergence and speciation can occur (Kisel and 116 Barraclough, 2010). Studies of marine tropical fauna (mostly fishes) have highlighted 117 the possible imporance of sympatric, ecological speciation in generating diversity 118 (Bowen et al., 2013; Rocha et al., 2005). This could also hold true for marine 119 macroalgae, but speciation modes are only rarely addressed for tropical seaweeds.

120 In the present study we assess species diversity and distributions on a global scale 121 focusing on the brown macroalga Lobophora (Dictyotales, Phaeophyceae). 122 Lobophora is a pan-tropico-temperate genus that has been previously documented in 123 the Atlantic (including he Gulf of Mexico), Indian and Pacific Oceans, across both 124 hemispheres (Vieira et al., 2016) (Fig.1; this study; Guiry and Guiry, 2015). Before 125 molecular data were available, virtually all specimens, regardless of their origin, had 126 been assigned to L. variegata (J.V.Lamour.) Womersley ex E.C.Oliveira, a species 127 that is now known to be restricted to the Caribbean (Vieira et al., 2016). Recent 128 molecular studies revealed that the biodiversity of this genus has been severely 129 underestimated (Schultz et al., 2015; Sun et al., 2012; Vieira et al., 2016; Vieira et al., 130 2014). This exceptional diversity discovered from limited locations in the Pacific and 131 Atlantic suggests the existence of a much greater diversity on a global level.

132 The present study aims to (1) assess species diversity on a global scale using 133 molecular data, (2) define current species distributional ranges, (3) determine the role 134 of dispersal barriers, and (4) examine spatial and temporal patterns of diversification 135 and dispersal of the genus Lobophora. 
2. Material and methods

\subsection{Taxon sampling}

139 Taxon sampling consisted of 598 Lobophora specimens. Sampling was carried out

140 from the intertidal down to $90 \mathrm{~m}$ deep by scuba diving, snorkeling, or box-dredging

141 (e.g. Gulf of Mexico). Specimens were sampled in more than 40 countries, spanning 142 the entire range of the genus (Fig. 1, Vieira et al., 2016 appendix). Voucher specimens 143 were preserved in silica gel and mounted on herbarium sheets. Collection information 144 and voucher/herbarium numbers are detailed in Vieira et al. (2016).

\subsection{DNA extraction, amplification and sequencing}

146 Total genomic DNA was extracted from tissue samples dried in silica gel, or in some 147 cases from herbarium specimens, using a cetyl-trimethyl ammonium bromide 148 (CTAB) extraction method following De Clerck et al. (2006) or using a DNeasy Plant 149 mini Kit (Qiagen, Hilden, Germany). Sequences were generated from the 150 mitochondrial encoded cytochrome c oxidase III gene (cox3), the chloroplast encoded 151 ribulose-1,5-biphosphate carboxylase $(r b c \mathrm{~L})$ and the photosystem II protein D1 152 ( $p s b A)$ genes. The datasets were complemented with sequences from GenBank (cf. 153 Vieira et al., 2016 appendix). Sequences were aligned using MUSCLE (Edgar, 2004) 154 implemented in eBioX 1.6 beta (Lagercrantz, 2008; available at: 155 http://www.ebioinformatics.org).

\section{2.3. Species delimitation}

157 Since traditional morphology-based species delimitation often yields inaccurate 158 estimates of seaweed diversity (Leliaert et al., 2014), we defined species exclusively 159 based on DNA sequence data. We applied different species delimitation methods i.e., 160 the Maximum Likelihood implementation of the GMYC model (Pons et al., 2006; 
161 Reid and Carstens, 2012), the Automatic Barcode Gap Discovery (ABGD; Puillandre 162 et al., 2012) and the Poisson Tree Processes model (PTP; Zhang et al., 2013) on the 163 cox3 dataset. The use of cox3 alone is enough for delineating species in Lobophora 164 (Vieira et al., 2014). GMYC and ABGD approaches were previously applied to define 165 Lobophora species from New Caledonia (Vieira et al., 2014) and the Western Atlantic 166 (Schultz et al., 2015). Application of the ML-GMYC on cox3 yielded highly similar 167 results (1) with other delimitation methods such as the Bayesian implementation of 168 the GMYC model and the Automatic Barcode Gap Discovery (Puillandre et al., 2012) 169 for the same marker, and (2) with analysis of the other markers, $r b c \mathrm{~L}$ and $p s b \mathrm{~A}$. 170 GMYC analyses under a single-threshold were conducted in R (R Core Team, 2014) 171 using the package "Splits" (Fujisawa and Barraclough, 2014; Monaghan et al., 2009). 172 The cox3 ultrametric tree, used to conduct the GMYC species delineation, was 173 constructed using Bayesian analyses in BEAST v1.8.2 (Drummond et al., 2012). A $174 \mathrm{GTR}+\mathrm{I}+\Gamma$ substitution model was identified as the best-fitting model for cox3, 175 based on the Akaike Information Criterion (AIC) using jModelTest 2 (Darriba et al., 176 2012). BEAST analyses were run under a relaxed molecular clock in combination 177 with a Yule tree prior. Other priors were set to default. In order to check for 178 convergence of the MCMC chains, we performed two independent runs for $10^{7}$ 179 generations each, starting from random trees and sampling every $10^{4}$ generations. 180 MCMC output files of the independent runs were inspected in Tracer v1.6 (Rambaut 181 et al., 2014) for acceptable effective sample sizes (ESS > 200). A burn-in of $25 \%$ was 182 applied once log-likelihood values had stabilized. Maximum clade credibility trees 183 and posterior probability for the nodes were calculated using the postburnin trees 184 using TreeAnnotator 1.8.2 (included in the BEAST package).

\section{2.4. Geographical scales}


186 Different hierarchical geographical scales were considered to assess the patterns of 187 diversity and historical biogeography analyses: (1) two basins: Atlantic and Indo188 Pacific; (2) three regions: Indo-Pacific, East Pacific and Atlantic; (3) five sub-regions: 189 Indo-Australian Archipelago (IAA; 'A' in Figs.5, 6), West Indo-Pacific ('B' in Figs.5, 190 6), Central Pacific ('C' in Figs.5, 6), East Pacific ('D' in Figs.5, 6) and Atlantic ('E' 191 in Figs.5, 6); and (4) 9 realms based on the Marine Ecoregions of the World from 192 Spalding et al. (2007): Temperate Northern Pacific, Central Indo-Pacific, Western 193 Indo-Pacific, Eastern Indo-Pacific, Tropical Eastern Pacific, Tropical Atlantic, 194 Temperate Northern Atlantic, Temperate Southern Africa and Temperate Australasia; 195 and also two climate zones: tropical and temperate.

\section{2.5. Species richness estimation and patterns of diversity}

197 Global species diversity was estimated using non-parametric richness estimators and extrapolation of the rarefaction curve (Shen et al., 2003). We used sample-based rarefaction, rescaled to number of individuals, to interpolate species richness per individual sampled, based on the analytical formulas of Colwell et al. (2004). Additionally, we computed three species richness estimators: the incidence-based coverage estimator (ICE; Chao and Lee, 1992), the Chao 2 richness estimators (Chao 2; Chao, 1987), and the first-order Jackknife richness estimator (Jack 1; Burnham and Overton, 1979). ICE distinguishes between frequent and infrequent species in analysis. Jack 1 does not differentiate the species frequency and relies on the number of species only found once. Chao 2 relies on the number of unique units and duplicates. Extrapolation of the rarefaction curve and species richness estimators were computed with the software EsTIMATES (Version 9; Colwell, 2013). We compared the observed and Chao 2 estimated species diversity between the marine sub-regions in order to compare the level of diversity in each of these regions. We compared the 
211 observed and Chao 2 estimated species diversity between four spatial scales i.e. local, 212 sub-regional, regional and global. We took the most well-sampled locality (New

213 Caledonia), realm (Central Indo-Pacific) and region (Indo-Pacific), in order to get the

214 best idea of what it takes in terms of sampling to properly assess species diversity at a

215 given spatial scale. Finally, to evaluate species range overlap between marine realms,

216 we calculated the similarity matrix between the nine marine realms with respect to

217 their species overlap, applying the Sørensen index (Magurran, 2013).

\section{2.6. Reconstruction of species phylogeny}

219 Based on the results of the species delimitation analyses, a concatenated alignment of 220 the $\operatorname{cox3}(610 \mathrm{bp})+p s b \mathrm{~A}(919 \mathrm{bp})+r b c \mathrm{~L}(1,360 \mathrm{bp})$ dataset was made containing a 221 single representative per species. The matrix was $80 \%$ filled at the species $\times$ gene 222 level. Species used as outgroup taxa used for the time-calibrated phylogeny are given 223 in Table S1. Maximum Likelihood (ML) and Bayesian Inference (BI) species trees 224 were generated from the concatenated alignment, partitioned by gene and codon 225 position. ML analyses were conducted using RAxML under a GTR+CAT model 226 (Stamatakis, 2006). The robustness of the resulting phylogenies was tested using 227 1,000 replicates of a rapid bootstrap heuristic (Stamatakis, 2006); and for the BI, 228 using MrBayes v3.2.2 (Ronquist and Huelsenbeck, 2003), initiated with a random 229 starting tree and with four chains of MCMC iterations ran simultaneously for 100 230 million generations. The first 100,000 (25\%) trees sampled were discarded as burn-in, 231 based on the stationarity of $\operatorname{lnL}$ for all parameters as assessed using Tracer version 1.6 232 (Rambaut et al., 2014). A consensus topology and posterior probabilities of the nodes 233 were calculated from the remaining trees. 
235 The occurrence of Phaeophyceae as fossils is rare due to their generally soft-bodied 236 nature (Arnold, 1947), and scientists continue to debate the identification of some 237 fossils (Coyer et al., 2001). Padina and Newhousia are the only two genera of the 238 class Phaeophyceae which deposit calcium carbonate. While no fossils of Newhousia 239 are documented to date, the Early Cretaceous (-145.5 to $-99.6 \mathrm{Ma}$ ) clay shales from 240 the Gangapur formation (Andhra Pradesh state, India) yielded a macroalgal fossil 241 reminiscent of extant species of the genus Padina (Rajanikanth, 1989). Babcock et al. 242 (2012) reported a new species of Padina from the Drumian Stage (Cambrian) in 243 Hunan, China. From our own observations of the available pictures, their 244 identification of a Padina is doubtful, and we decided not to consider this fossil since 245 it is challenging the current view of the time-scale of brown algal evolution (Brown \& 246 Sorhannus, 2010). Our Lobophora phylogeny was therefore calibrated with (1) a 247 fossil of Padina, (2) the Dictyotales node as estimated in Silberfeld et al. (2010), and 248 (3) the Phaeophyceae node as estimated in Brown and Sorhannus (2010). The age of 249 Padina was constrained at $-95 \mathrm{Ma}$ and tailing off according to a gamma distribution 250 with shape $=3.0$ and scale $=5.5$ (Silberfeld et al., 2014). The split between the 251 Dictyotales and the outgroup Syringoderma, i.e. the crown group Dictyotales252 Syringoderma, was constrained between -130 and -195 Ma using a uniform prior 253 (Silberfeld et al., 2014). The age of the split between Phaeophyceae and 254 Schizocladiophyceae lineages, i.e. the crown group Phaeophyceae255 Schizocladiophyceae, was constrained in the Lower Jurassic between -125 and -253 256 Ma using a uniform prior (Brown and Sorhannus, 2010). The time-calibrated 257 Lobophora phylogeny (i.e. chronogram) was inferred using Bayesian analyses in 258 BEAST 1.8.2 (Drummond et al., 2012), for the concatenated (cox3 $+r b c \mathrm{~L}+p s b \mathrm{~A})$ 259 alignment partitioned by gene and codon position, using a lognormal relaxed 
molecular clock method, with autocorrelated rates in combination with a Yule model

261 tree prior, and the GTR $+\mathrm{I}+\Gamma$ substitution model for the three unlinked markers.

262 The GTR + I $+\Gamma$ substitution model was identified as the best-fitting model for each

263 gene, based on the Akaike Information Criterion (AIC) using jModelTest 2 (Darriba

264 et al., 2012). Other priors were set to default. In order to check for convergence of the

265 MCMC chains, we performed two independent runs for $10^{7}$ generations each, starting

266 from random trees and sampling every $10^{4}$ generations. MCMC output files of the

267 independent runs were inspected in Tracer v1.6 (Miller et al., 2010) for acceptable

268 effective sample sizes (ESS > 200). A burn-in was applied once log-likelihood values

269 for all parameters had stabilized. Maximum clade credibility trees and posterior 270 probabilities for the nodes were calculated using the postburnin trees using

271 TreeAnnotator 1.8.2 (included in the BEAST package). All phylogenetic analyses

272 were conducted on the Cipres web portal (Miller et al., 2010).

$273 \quad$ 2.8. Historical biogeography

274 To infer the evolution of geographical ranges, we used the $\mathrm{R}$ package BIOGEOBEARS

275 (Matzke, 2013). This package implements the most common biogeographical history

276 reconstruction methods in a likelihood framework: dispersal-extinction-cladogenesis

277 model (DEC; Ree et al., 2005; Ree and Smith, 2008), dispersal-vicariance analysis

278 (DIVA; Ronquist, 1997) and the BayArea model (Landis et al., 2013). Moreover, it

279 also incorporates a model of founder-event speciation (' $+\mathrm{J}$ ') and allows the fit of 280 models to be compared using a model choice procedure (Matzke, 2013).

282 3. Results

283 3.1. Lobophora global species diversity 
284 The GMYC analysis based on the mitochondrial cox3 marker, significantly rejected 285 the null model (single coalescence model for the entire tree), resulting in delimitation 286 of 109 evolutionary significant units (ESUs) (Fig. 2), with a confidence interval of 98 287 - 121. ABGD and PTP resulted in the delineation of 100 and 141 ESUs, 288 respectiveley. ABGD lineages were subdivided 5 and 26 times by GMYC and PTP, 289 respectively. Subdivisions of GMYC and ABGD lineages in the PTP delineation, 290 generally reflected the biogeography of the lineages, i.e. sibling lineages in PTP are 291 geographically distinct. For example L. sp.35 split into two lineages in the PTP 292 analysis, which correspond to two regions, namely South Africa and Juan de Nova. 293 For this study, we considered the GMYC delineation results since the geographic 294 distances between these additional species delineated by PTP generally did not extend 295 further than within a marine region.

296 Extrapolation of the rarefaction curve indicates a mean value of 190 Lobophora 297 species, with a confidence interval of $140-235$ species (Fig. S1). The species 298 diversity value reaches a plateau at ca. 3000 samples. Species richness estimators 299 projected a diversity of 179 (Jack 1) to 209 (ICE) species (Table1). Taking the mean 300 and the confidence interval of the GMYC results into consideration, and estimators 301 and extrapolation values, we estimate having discovered 42 to $86 \%$ of the Lobophora 302 extant species diversity (Table 1).

\subsection{Regional diversity}

305 Substantial differences in species diversity were observed between some marine sub306 regions. The Indo-Pacific stands out with the highest diversity with 95 species and an 307 estimate of 150 species based on the Chao2 species richness estimator (Fig. 3A, S2A). 308 The level of diversity drops to 18 species in the Atlantic with an estimate of 20 
species based on Chao2 (Fig. 3A, S2A). The least speciose regions are Temperate

310 Australasia and the Tropical Eastern Pacific with six and four species, respectively,

311 and with similar Chao 2 based-estimates (Fig. 3A, S2A). We also examined species

312 diversity along a multiscale gradient from a local (i.e. New Caledonia) to a global

\$13 scale (Fig. 3B, S2B). Fig. 3 displays the cumulative number of species observed as a

314 function of sampling effort in different marine regions (Fig. 3A, S2A) and at different

315 scales (Fig. 3B, S2B). The shape of the curves is not the same for all regions, with

316 three out of four approximately reaching an asymptote shape, implying that the Indo-

317 Pacific region reserves a greater diversity yet to be explored, while the diversity of the

318 other regions was mostly revealed by our sampling.

\subsection{Inter-regional species overlap}

\$21 Twenty-five percent of all Lobophora species span more than one sub-region (Fig. 6).

322 With 16 species shared with neighbouring sub-regions (nine with the Western Indo-

323 Pacific and seven with the Eastern Indo-Pacific) the Indo-Australian Archipelago is 324 the sub-region that shares the most species with its adjacent sub-regions (Fig. 6). The tropical Eastern Pacific, which shares no species with the Eastern Indo-Pacific and only one species with the Atlantic (Fig. 6), is the most 'isolated' region followed by the Atlantic (Fig. 6). A Sørensen similarity matrix shows an overall low similarity $(<0.20)$ between the nine marine realms in terms of species overlap (Table S2), meaning that a limited number of species span more than one realm. The highest level of similarity (0.92) is observed between the Tropical Atlantic and Temperate

331 Northern Atlantic, which have four species in common. Despite the high diversity in 332 the Indo-Pacific, provinces display low species overlap. 


\subsection{Geographical diversity patterns}

335 The Central Indo-Pacific is the richest realm with at least 57 species, followed by the

336 Western Indo-Pacific with 35 species, the Eastern Indo-Pacific with 19 species and 337 the Tropical Atlantic with 14 species. The remaining realms contain between one to 6 \$38 species (Table 2). Only three species are occurring across both hemispheres ( $L$. 339 asiatica, L. sp.18 and L. sp44). Ninety-nine Lobophora species (87\%) are strictly 340 tropical, 5 species $(4 \%)$ are strictly temperate and 10 species (9\%) are tropico\$41 temperate (present in warm temperate and tropical regions). Nearly all Lobophora 342 species $(109$ species $=97 \%)$ are restricted to one ocean basin (Table 2), and 86 343 species $(75 \%)$ are restricted to one marine realm (Table 2). Twenty-three (20\%) and 344 five $(3.5 \%)$ species are spanning two and three realms, respectively. In the Indo\$45 Pacific, only four species are distributed across the centro-western part (L. sp28 (8 specimens), L. rosacea (67 specimens), L. gibbera (7 specimens), L. ceylanica (5 347 specimens)) and only three in the centro-eastern part (L. pacifica (11 specimens), L. undulata (31 specimens), L. sp19 (20 specimens)), but in our dataset no species are 349 found across the entire the Indo-Pacific.

\subsection{Dated molecular phylogeny of Lobophora}

352 A Lobophora species tree, infered from a concatenated alignment of $r b c \mathrm{~L}, \operatorname{cox} 3$ and 353 psbA sequences, presented with maximum-likelihood bootstrap and Bayesian 354 posterior probability values, is given in Fig. S3. Our time-calibrated phylogeny 355 indicates that Lobophora originated in the Upper Cretaceous between 65 - $90 \mathrm{MY}$ 356 (Fig. 4). From the beginning of the Cenozoic onward, Lobophora diversification 357 occurred rather steadily through its evolutionary history (Fig. 4). None of the major 358 marine vicariance events (e.g. closure of the Tethys Sea, Benguela upwelling, Panama 
359 Isthmus closure; indicated as vertical lines in Fig. 4) nor sea level variations 360 (indicated as a blue line in Fig. 4) seem to have caused major shifts in diversification 361 rates of Lobophora. On the other hand, the East Pacific barrier represents a clear 362 dispersal barrier since the East Pacific has a lower number of Lobophora species, and 363 only three that span the central and eastern Pacific.

\section{3.6. Historical biogeographical inference}

365 The Dispersal-Extinction-Cladogenesis with founder-event speciation model (DEC+

366 J) was identified as the best model in the BioGeoBEARS analyses when considering \$67 nine marine realms or five marine sub-regions (Table 3). These results highlight the 368 importance of founder-event speciation $(j=0.0254>d=0.0019>\mathrm{e}=0)$. When the 369 number of regions was reduced to three (Atlantic, Indo-Pacific and Eastern Pacific) or 370 two (Atlantic and Indo-Pacific), DIVA $+\mathrm{J}$ was identified as the best model. Based on 371 the historical biogeographical inference based on the basins level (Atlantic and Indo372 Pacific), the DEC $+\mathrm{J}$ model informs us that the Lobophora ancestor (LA) originated 373 from the Indo-Pacific which corresponded to the Upper Cretaceous Tethys Sea (Figs. $3744,5)$.

\subsection{Relative contribution of sympatry, vicariance and founder events}

“Biogeographical Stochastic Mapping” (BSM), implemented in BioGeoBEARS, allows to quantify speciation events. 'Sympatric' speciation, i.e. speciation within a predefined region, comes as the most important speciation mode (90\%) at the basin 379 level, with the remaining $10 \%$ being founder events, e.g. dispersal from one basin on \$80 to another. At a finer scale, i.e. marine realms level, speciation within marine regions 381 remains the most important mode of speciation $(71 \%)$, followed by founder events $382(19 \%)$ and vicariance $(9 \%)$. The relative contribution of each of these modes of 383 speciation varies between the different realms (Figs. 6,S5). For instance, while most 
of Lobophora diversity within the Central Indo-Pacific and the Western Indo-Pacific result from 'sympatric' speciation, Lobophora diversity within the Temperate Northern Pacific and Temperate Southern Africa exclusively results from founder events (Figs. 6,S5).

\section{Discussion}

\subsection{Species diversity}

391 We assessed species diversity of the marine brown algal genus Lobophora on a global scale. The level of Lobophora diversity unveiled from local studies in the Pacific Ocean (Sun et al., 2012; Vieira et al., 2014) already predicted a richer global 394 biodiversity for this genus than previously recognized. Our DNA sequence data 395 indicate an increase of the species diversity of the genus Lobophora by five to six folds, from 20-30 species to more than 100 species, which makes Lobophora a hyperdiverse genus of marine macroalgae. Our results once again show how morphology-based taxonomy fails to accurately estimate species diversity in some algal groups (De Clerck et al., 2013; Leliaert et al., 2014; Packer et al., 2009).

\subsection{Geographic distributions}

401 While sister species may be geographically widely separated (Fig. S4), the 402 distribution of single species are mostly restricted to one ocean basin and usually do 403 not expand beyond marine realms as defined by Spalding et al. (2007), but there are 404 exceptions, namely $L . \operatorname{sp} 37, L$. sp44 and $L$. sp77, which are spanning beyond the 405 Atlantic. Not a single Lobophora species was found to be pantropical, i.e. 406 cosmopolitan. Several other algal taxa with allegedly broad distribution have been 407 shown to correspond to complexes of species with restricted distributions. A study 408 conducted on the genus Padina (Silberfeld et al., 2014) (a member of the same family 
410 segregated into evolutionary lineages with more restricted ranges. Working on two

411 supposedly circumtropical Dictyota species (also Dictyotaceae), D. ciliolata and D.

412 crenulata, Tronholm et al. (2012) concluded that the former consisted of several

413 pseudocryptic species with restricted distributions in the Atlantic Ocean and Pacific

414 Central America, while the pantropic distribution of the latter was confirmed. Other

415 examples can be given, such as Colpomenia sinuosa which consist of several species

416 with more or less wide distribution (Lee et al., 2013). Although red algae may have a

417 different evolutionary history, at a finer geographical scale, Zuccarello and West

418 (2003) study on the Bostrychia radicans/B. moritziana complex resulted in the

419 identification of distinct evolutionary lineages with defined areas along the eastern

420 North American coast.

\section{4.3. Patterns of diversity}

422 The majority of the Lobophora species are restricted to tropical regions, and have 423 small ranges limited to marine realms. Lobophora species diversity is highest in the 424 Indo-Australian Archipelago (IAA). In contrast to the general patterns of most 425 macroalgal genera (e.g. Santelices and Marquet, 1998), the center of diversity for the 426 genus Lobophora is located in the tropics. Similar patterns are observed among 427 several other macroalgal groups such as siphonous green algae (Kerswell, 2006), but 428 also genera belonging to the same order as Lobophora, i.e. Dictyota (Guiry and Guiry, 429 2015) and Padina (Silberfeld et al., 2014). In the Atlantic Ocean, the center of 430 diversity is located in the central Caribbean. However, diversity in the Atlantic (14 431 species) is much lower compared to the Indo-Pacific (102 species). Several possible 432 explanations have been discussed in the literature, e.g. greater diversity and extent of 433 shallow water habitats in the central Indo-Pacific compared to the Atlantic (both 
434 historically and today); bigger size of the tropical Indo-Pacific, and higher number of 435 islands, relative to the Atlantic, providing more opportunities for isolation and 436 speciation; greater age of the Indo-Pacific; increased diversification in Oligo-Miocene 437 related to tectonic activity in central IWP (e.g. collision of Australia-New Guinea 438 plate with SE Eurasia) increasing shallow water habitats (Williams and Duda Jr,

439 2008); increased speciation by isolation and reconnection of Indo-Pacific populations 440 as sea levels drop and rise (e.g. during Pleistocene glaciation events); ecological 441 speciation (e.g. Bowen et al., 2013, see discussion below). Then, there is the classical 442 discussion whether the high diversity in the central Indo-Pacific is the result of high 443 speciation rates within the region (center of origin), speciation in peripheral regions 444 and dispersal and survival in the central IP (center of accumulation), or the result of 445 overlapping ranges (center of overlap) (Barber and Meyer, 2015).

\section{4.4. Tethyan diaspora: origin and early diversification}

447 The time-calibrated phylogeny and historical biogeographical analysis suggest that 448 Lobophora originated in the Upper Cretaceous in the remains of the Tethys Sea. 449 Origination in the Tethys Sea is inferred, yet with a high level of uncertainty, as 450 possible/putative ancestral area a region common to the current Atlantic and Indo451 Pacific Oceans. On the other hand the ancestral range of the large clade 452 emcompassing L. sp61 as outgroup, that originated $-55 \mathrm{My}$, is inferred to be the 453 Central Indo-Pacific with high certainty. From the Tethys Sea, Lobophora species 454 experienced multiple, more recent, dispersal events to the Atlantic, with little 455 diversification within the region. Diversification has been considerably higher in the 456 Indo-West Pacific compared to the Atlantic and Eastern Pacific (see discussion 457 above). Nevertheless, dispersal events in the Atlantic Ocean may have occurred more 458 recently than during the Upper Cretaceous (e.g. Oligocene and Miocene) which could 
explain why the number of species is lower in the Atlantic. In fact, while Atlantic species branched off early in the tree, dispersal events could have taken place anywhere along these branches (e.g. the actual dispersal event could have taken place

462 close to the nodes of Atlantic clades). Generally, founder speciation occurred several 463 times throughout Lobophora evolutionary history thus playing an important role in its 464 diversification. High diversity within the Central Indo-Pacific region may have 465 resulted from a combination of within region speciation and of regular colonization 466 from adjacent regions (West Indo-Pacific and Eastern Indo-Pacific; Fig. 6).

467 Furthermore, $70 \%$ of the species distributed within at least two different marine 468 realms are present in the Central Indo-Pacific. These observations suggest that this 469 region acted not only as a region of origination/diversification but also a center of 470 overlap (Barber, 2009; Connolly et al., 2003; Halas and Winterbottom, 2009). 471 Colonization of the Caribbean occurred several times and from different origins, and 472 resulted in very low regional diversification (e.g. Altantic clades of maximum two 473 species). The presence of only two species ( $L . \operatorname{sp} 44$ and $L$. sp37) distributed in the 474 Western Indo-Pacific and in the Eastern Atlantic also suggests that while the 475 Benguela upwelling may represent an efficient dispersal barrier, dispersal across it 476 occurred at least twice. Finally, colonization of temperate regions occurred at 477 different periods of Lobophora evolution history. The earliest dispersal to temperate 478 region occurred during the Paleocene $(-60 \mathrm{Ma})$ in the southern hemisphere. Northern 479 hemisphere temperate regions were colonized more recently. The current global 480 Lobophora taxonomic makeup shows that hard barrier formations (East Pacific 481 Barrier, Terminal Tethyan event, Isthmus of the Panama) did not act as important 482 vicariance events for this genus (Fig. 4). On the other hand, they constituted efficient 483 barriers for Lobophora dispersal. However, while no sibling species were yet found 
across the Panama isthmus, it is not excluded that a more significant sampling effort on the Pacific side of the isthmus could disclose sibling species.

\subsection{Geographical speciation processes}

487 It is important to note that the term 'sympatric' speciation expresses here speciation 488 within the scale considered (e.g. basin, region, realm). Within a given region, 489 however, speciation may actually result from allopatric speciation (e.g. vicariance or 490 founder event). Identifying actual sympatric speciation events requires working at the 491 finest possible scale e.g. several hundred meters to several hundred kilometers.

492 We analyzed diversification at different scales from ocean basins to the marine 493 realms. Virtually all speciation events occurred within ocean basins, and two-third of 494 the speciation events occurred within marine realms. On the other hand, long-distance 495 dispersal to adjacent realms, followed by founder speciation represents a nonnegligible process in Lobophora diversification. It is difficult, however, to make sound conclusions regarding geographical versus ecological speciation modes based on our data. Within realms, the finest scales considered in this study, sympatric and/or 499 allopatric speciation could have occurred. Finer phylogeographic studies, down to scales of several kilometers, in combination with ecological data, will be needed to assess the relative role of allopatric versus sympatric speciation in Lobophora (e.g. Billard et al., 2010; Payo et al., 2013; Pielou, 1978). The wide ecological variation in

503 Lobophora hints toward an important role of ecological speciation. In addition, 504 ecological partitioning has been shown to allow coexistence of sympatric Lobophora 505 sister species (Vieira et al., 2014) often found only several meters apart.

\section{4.6. Cladogenic drivers}

507 Lobophora species distribution and richness are reminiscent of those of corals and 508 coral reef fishes (Cowman and Bellwood, 2011). Several studies have already pointed 
to the central role of coral reef association in underpinning diversification within

510 major marine groups (Alfaro et al., 2007; Bellwood et al., 2010; Cowman and

511 Bellwood, 2011; Hughes et al., 2002; Renema et al., 2008). Considering the major 512 role herbivory played in macroalgal ecology (Hay, 1997; Lubchenco and Gaines, 513 1981), diversification of reef algae and herbivores are very likely correlated through a 514 co-evolutionary arms race. The development of a complex mosaic of reef habitats also 515 probably favored reef algal speciation by providing opportunities for new habitat 516 colonization and ecological diversification (Alfaro et al., 2007; Cowman and 517 Bellwood, 2011). Thus, the biotic interactions between Lobophora, herbivores and 518 corals may have favored diversification in coral reefs. This idea that coral reefs acted 519 as cladogenesis drivers has already been proposed for other reef organisms, such as 520 coral reef fishes, where coral reefs provided the mechanisms allowing both higher 521 rates of speciation and reduced vulnerability to extinction for associated lineages 522 (Cowman and Bellwood, 2011).

523 Lobophora has been considered as a potent competitor with corals. An example is its 524 proliferation following disturbances that impacted herbivores and corals in the 525 Caribbean in the mid-80s (De Ruyter van Steveninck and Breeman, 1987; Hughes, 526 1994). Timing of origination and patterns of distribution and diversity clearly show 527 that Lobophora is a fully-fledged member of coral reefs and has evolved in these 528 ecosystems since the rise of modern coral reefs (during the Cretaceous). 529 Consequently, Lobophora should not be seen as a threat to corals, but instead as an 530 indicator of coral reef health status. In fact, while following disturbances, Lobophora 531 has shown the capacity to bloom in certain reefs across the globe (De Ruyter van 532 Steveninck and Breeman, 1987; Diaz-Pulido et al., 2009; Lesser and Slattery, 2011), 533 and corals demonstrated resilience once conditions came back to normal (Diaz-Pulido 
534 et al., 2009). In healthy reefs, Lobophora has been reported only once as representing 535 an apparent threat to corals (Vieira et al., 2015), a case of epizoism syndrome, but 536 even then, only one species was threatened.

538 Acknowledgments

539 C. Vieira is a PhD fellow of the University of Pierre and Marie Curie and Ghent

540 University and is part of MARES, a Joint Doctorate program selected under Erasmus

541 Mundus coordinated by Ghent University (FPA 2011-0016). O. Camacho is a PhD

542 Candidate at the University of Louisiana at Lafayette. We thank NSF DEB-0315995 543 and DEB-1456674 (ARTS). 


\section{Reference}

Adams, M., Raadik, T.A., Burridge, C.P., Georges, A., 2014. Global biodiversity assessment and hyper-cryptic species complexes: more than one species of elephant in the room? Syst. Biol. 63, 518-533.

Agapow, P.M., Bininda-Emonds, O.R., Crandall, K.A., Gittleman, J.L., Mace, G.M., Marshall, J.C., Purvis, A., 2004. The impact of species concept on biodiversity studies. Q. Rev. Biol. 79, 161-179.

Alfaro, M.E., Santini, F., Brock, C.D., 2007. Do reefs drive diversification in marine teleosts? Evidence from the pufferfish and their allies (Order Tetraodontiformes). Evolution 61, 2104-2126.

Appeltans, W., Ahyong, S.T., Anderson, G., Angel, M.V., Artois, T., Bailly, N., Bamber, R., Barber, A., Bartsch, I., Berta, A., 2012. The magnitude of global marine species diversity. Curr. Biol. 22, 2189-2202.

Arnold, C.A., 1947. Introduction to paleobotany.

Barber, P.H., 2009. The challenge of understanding the Coral Triangle biodiversity hotspot. J. Biogeogr. 36, 1845-1846.

Barber, P.H., Meyer, C.P., 2015. Pluralism explains diversity in the Coral Triangle. In: Mora, C. (Ed.), Ecology of Fishes on Coral Reefs. Cambridge University Press, p. 258.

Bellwood, D., Klanten, S., Cowman, P., Pratchett, M., Konow, N., Van Herwerden, L., 2010. Evolutionary history of the butterflyfishes (f: Chaetodontidae) and the rise of coral feeding fishes. J. Evol. Biol. 23, 335-349.

Bickford, D., Lohman, D.J., Sodhi, N.S., Ng, P.K., Meier, R., Winker, K., Ingram, K.K., Das, I., 2007. Cryptic species as a window on diversity and conservation. Trends Ecol. Evol. 22, 148-155.

Billard, E., Serrão, E., Pearson, G., Destombe, C., Valero, M., 2010. Fucus vesiculosus and spiralis species complex: a nested model of local adaptation at the shore level. Mar. Ecol. Prog. Ser. 405, 163-174.

Blaxter, M.L., 2004. The promise of a DNA taxonomy. Phil. Trans. R. Soc. B 359, 669-679.

Bowen, B.W., Rocha, L.A., Toonen, R.J., Karl, S.A., 2013. The origins of tropical marine biodiversity. Trends Ecol. Evol. 28, 359-366.

Brown, J.W., Sorhannus, U., 2010. A molecular genetic timescale for the diversification of autotrophic stramenopiles (Ochrophyta): substantive underestimation of putative fossil ages. PLoS One 5, e12759.

Burnham, K.P., Overton, W.S., 1979. Robust estimation of population size when capture probabilities vary among animals. Ecology 60, 927-936.

Chao, A., 1987. Estimating the population size for capture-recapture data with unequal catchability. Biometrics 43, 783-791.

Chao, A., Lee, S.M., 1992. Estimating the Number of Classes Via Sample Coverage. J. Amer. Statist. Assoc. 87, 210-217.

Colwell, R., 2013. EstimateS: Statistical estimation of species richness and shared species from samples. (http://purloclcorg/estimates), Version 9.

Colwell, R.K., Mao, C.X., Chang, J., 2004. Interpolating, extrapolating, and comparing incidence-based species accumulation curves. Ecology 85, 2717-2727.

Connolly, S.R., Bellwood, D.R., Hughes, T.P., 2003. Indo-Pacific biodiversity of coral reefs: deviations from a mid-domain model. Ecology 84, 2178-2190. 
Costello, M.J., May, R.M., Stork, N.E., 2013. Can we name Earth's species before they go extinct? Science 339, 413-416.

Cowman, P., Bellwood, D., 2011. Coral reefs as drivers of cladogenesis: expanding coral reefs, cryptic extinction events, and the development of biodiversity hotspots. J. Evol. Biol. 24, 2543-2562.

Coyer, J.A., Smith, G.J., Andersen, R.A., 2001. Evolution of Macrocystis spp. (Phaeophyceae) as determined by ITS1 and ITS2 sequences. J. Phycol. 37, 574-585.

Darriba, D., Taboada, G.L., Doallo, R., Posada, D., 2012. jModelTest 2: more models, new heuristics and parallel computing. Nat. Methods 9, 772-772.

De Clerck, O., Gavio, B., Fredericq, S., Barbara, I., Coppejans, E., 2005. Systematics of Grateloupia fillicina (Halumeniaceae, Rhodophyta), based on $r b c \mathrm{~L}$ sequence analyses and morphological evidence, including the reinstatement of $G$. minima and the description of $G$. capensis sp. nov. J. Phycol. 41, 391-410.

De Clerck, O., Guiry, M.D., Leliaert, F., Samyn, Y., Verbruggen, H., 2013. Algal taxonomy: a road to nowhere? J. Phycol. 49, 215-225.

De Clerck, O., Leliaert, F., Verbruggen, H., Lane, C.E., De Paula, J.C., Payo, D.A., Coppejans, E., 2006. A revised classification of the Dictyoteae (Dictyotales, Phaeophyceae) based on $r b c \mathrm{~L}$ and 26S ribosomal DNA sequence analyses. J. Phycol. 42, 1271-1288.

De Ruyter van Steveninck, E., Breeman, A., 1987. Deep water vegetations of Lobophora variegata (Phaeophyceae) in the coral reef of Curacaopopulation dynamics in relation to mass mortality of the sea urchin Diadema antillarum. Mar. Ecol. Prog. Ser. 36, 81-90.

De Vargas, C., Audic, S., Henry, N., Decelle, J., Mahé, F., Logares, R., Lara, E., Berney, C., Le Bescot, N., Probert, I., 2015. Eukaryotic plankton diversity in the sunlit ocean. Science 348, 1261605.

Diaz-Pulido, G., McCook, L.J., Dove, S., Berkelmans, R., Roff, G., Kline, D.I., Weeks, S., Evans, R.D., Williamson, D.H., Hoegh-Guldberg, O., 2009. Doom and boom on a resilient reef: climate change, algal overgrowth and coral recovery. PLoS One 4, e5239.

Drummond, A.J., Suchard, M.A., Xie, D., Rambaut, A., 2012. Bayesian phylogenetics with BEAUti and the BEAST 1.7. Mol. Biol. Evol. 29, 1969-1973.

Edgar, R.C., 2004. MUSCLE: multiple sequence alignment with high accuracy and high throughput. Nucleic Acids Res. 32, 1792-1797.

Evans, K.M., Wortley, A.H., Mann, D.G., 2007. An assessment of potential diatom "barcode" genes (cox1, rbcL, 18S and ITS rDNA) and their effectiveness in determining relationships in Sellaphora (Bacillariophyta). Protist 158, 349-364.

Fraser, C.I., Zuccarello, G.C., Spencer, H.G., Salvatore, L.C., Garcia, G.R., Waters, J.M., 2013. Genetic affinities between trans-oceanic populations of nonbuoyant macroalgae in the high latitudes of the Southern Hemisphere. PLoS One 8, e69138.

Grosberg, R.K., Vermeij, G.J., Wainwright, P.C., 2012. Biodiversity in water and on land. Curr. Biol. 22, R900-R903.

Guiry, M.D., 2012. How many species of algae are there? J. Phycol. 48, 1057-1063. 
Guiry, M.D., Guiry, G.M., 2015. AlgaeBase. World-wide electronic publication. National University of Ireland, Galway. http://www.algaebase.org (accessed 30 Oct 2016).

Halas, D., Winterbottom, R., 2009. A phylogenetic test of multiple proposals for the origins of the East Indies coral reef biota. J. Biogeogr. 36, 1847-1860.

Hay, M.E., 1997. The ecology and evolution of seaweed-herbivore interactions on coral reefs. Coral Reefs 16, Suppl.: S67-S76.

Hughes, T.P., 1994. Catastrophes, phase shifts, and large-scale degradation of a Caribbean coral reef. Science 265, 1547-1551.

Hughes, T.P., Bellwood, D.R., Connolly, S.R., 2002. Biodiversity hotspots, centres of endemicity, and the conservation of coral reefs. Ecol. Lett. 5, 775-784.

Kerswell, A.P., 2006. Global biodiversity patterns of benthic marine algae. Ecology 87, 2479-2488.

Kinlan, B.P., Gaines, S.D., 2003. Propagule dispersal in marine and terrestrial environments: a community perspective. Ecology 84, 2007-2020.

Kirkendale, L., Saunders, G.W., Winberg, P., 2013. A molecular survey of Ulva (Chlorophyta) in temperate Australia reveals enhanced levels of cosmopolitanism. J. Phycol. 49, 69-81.

Kisel, Y., Barraclough, T.G., 2010. Speciation Has a Spatial Scale That Depends on Levels of Gene Flow. Am. Nat. 175, 316-334.

Lagercrantz, E., 2008. eBioX. Available at http://www.ebioinformatics.org/ebiox [accessed 30 Jun 2016].

Landis, M.J., Matzke, N.J., Moore, B.R., Huelsenbeck, J.P., 2013. Bayesian Analysis of Biogeography when the Number of Areas is Large. Syst. Biol. 62, 789804.

Lee, K.M., Boo, G.H., Coyer, J.A., Nelson, W.A., Miller, K.A., Boo, S.M., 2014. Distribution patterns and introduction pathways of the cosmopolitan brown alga Colpomenia peregrina using mt cox3 and atp6 sequences. J. Appl. Phycol. 26, 491-504.

Lee, K.M., Boo, S.M., Sherwood, A.R., 2013. Cryptic diversity and biogeography of the widespread brown alga Colpomenia sinuosa (Ectocarpales, Phaeophyceae). Bot. Mar. 56, 15-25.

Leliaert, F., Verbruggen, H., Vanormelingen, P., Steen, F., López-Bautista, J.M., Zuccarello, G.C., De Clerck, O., 2014. DNA-based species delimitation in algae. Eur. J. Phycol. 49, 179-196.

Leliaert, F., Verbruggen, H., Wysor, B., De Clerck, O., 2009. DNA taxonomy in morphologically plastic taxa: algorithmic species delimitation in the Boodlea complex (Chlorophyta: Cladophorales). Mol. Phylogen. Evol. 53, 122-133.

Lesser, M.P., Slattery, M., 2011. Phase shift to algal dominated communities at mesophotic depths associated with lionfish (Pterois volitans) invasion on a Bahamian coral reef. Biol. Invasions 13, 1855-1868.

Lubchenco, J., Gaines, S.D., 1981. A unified approach to marine plant-herbivore interactions. I. Populations and communities. Annu. Rev. Ecol. Syst., 405437.

Macaya, E.C., Zuccarello, G.C., 2010. DNA barcoding and genetic diverfence in the giant kelp Macrocystis (Laminariales). J. Phycol. 46, 736-742.

Magurran, A.E., 2013. Measuring biological diversity. Blackwell, Oxford, United Kingdom. 
Matzke, N.J., 2013. BioGeoBEARS: Biogeography with Bayesian (and likelihood) evolutionary analysis in R scripts. R package, version 0.21 .

May, R.M., Godfrey, J., 1994. Biological Diversity: Differences between Land and Sea [and Discussion]. Phil. Trans. R. Soc. B 343, 105-111.

Miller, K.G., Kominz, M.A., Browning, J.V., Wright, J.D., Mountain, G.S., Katz, M.E., Sugarman, P.J., Cramer, B.S., Christie-Blick, N., Pekar, S.F., 2005. The Phanerozoic record of global sea-level change. Science 310, 1293-1298.

Miller, M.A., Pfeiffer, W., Schwartz, T., 2010. Creating the CIPRES Science Gateway for inference of large phylogenetic trees. In: Proceedings of the Gateway Computing Environments Workshop (GCE). Institute of Electrical and Electronics Engineers (IEEE), New Orleans. New York, USA, pp. 1-8.

Mora, C., Tittensor, D.P., Adl, S., Simpson, A.G., Worm, B., 2011. How many species are there on Earth and in the ocean? PLoS Biol. 9, e1001127.

Norton, T.A., 1992. Dispersal by Macroalgae. Brit. Phycol. J. 27, 293-301.

Packer, L., Gibbs, J., Sheffield, C., Hanner, R., 2009. DNA barcoding and the mediocrity of morphology. Mol. Ecol. Resour. 9, 42-50.

Payo, D.A., Leliaert, F., Verbruggen, H., D'hondt, S., Calumpong, H.P., De Clerck, O., 2013. Extensive cryptic species diversity and fine-scale endemism in the marine red alga Portieria in the Philippines. Proc. R. Soc. Lond. B. Biol. Sci. 280, 20122660.

Pfenninger, M., Schwenk, K., 2007. Cryptic animal species are homogeneously distributed among taxa and biogeographical regions. BMC Evol. Biol. 7, 121.

Pielou, E.C., 1978. Latitudinal Overlap of Seaweed Species - Evidence for QuasiSympatric Speciation. J. Biogeogr. 5, 227-238.

Pons, J., Barraclough, T.G., Gomez-Zurita, J., Cardoso, A., Duran, D.P., Hazell, S., Kamoun, S., Sumlin, W.D., Vogler, A.P., 2006. Sequence-based species delimitation for the DNA taxonomy of undescribed insects. Syst. Biol. 55, 595-609.

Puillandre, N., Lambert, A., Brouillet, S., Achaz, G., 2012. ABGD, Automatic Barcode Gap Discovery for primary species delimitation. Mol. Ecol. 21, 1864-1877.

Rajanikanth, A., 1989. A fossil marine brown alga from the Gangapur Formation, Pranhita-Godavari Graben. Curr. Sci. 58, 78-80.

Rambaut, A., Suchard, M., Xie, D., Drummond, A., 2014. Tracer v1.6. Molecular evolution, phylogenetics and epidemiology, University of Edinburgh. http://beast.bio.ed.ac.uk/Tracer.

Ree, R.H., Moore, B.R., Webb, C.O., Donoghue, M.J., 2005. A likelihood framework for inferring the evolution of geographic range on phylogenetic trees. Evolution 59, 2299-2311.

Ree, R.H., Smith, S.A., 2008. Maximum likelihood inference of geographic range evolution by dispersal, local extinction, and cladogenesis. Syst. Biol. 57, 414.

Reid, N., Carstens, B., 2012. Phylogenetic estimation error can decrease the accuracy of species delimitation: a Bayesian implementation of the general mixed Yule-coalescent model. BMC Evol. Biol. 12, 196.

Renema, W., Bellwood, D., Braga, J., Bromfield, K., Hall, R., Johnson, K., Lunt, P., Meyer, C., McMonagle, L., Morley, R., 2008. Hopping hotspots: global shifts in marine biodiversity. Science 321, 654-657. 
Rocha, L.A., Robertson, D.R., Roman, J., Bowen, B.W., 2005. Ecological speciation in tropical reef fishes. Proc. R. Soc. Lond. B. Biol. Sci. 272, 573-579.

Ronquist, F., 1997. Dispersal-vicariance analysis: a new approach to the quantification of historical biogeography. Syst. Biol. 46, 195-203.

Ronquist, F., Huelsenbeck, J.P., 2003. MrBayes 3: Bayesian phylogenetic inference under mixed models. Bioinformatics 19, 1572-1574.

Santelices, B., 1990. Patterns of reproduction, dispersal and recruitment in seaweeds. Oceanogr. Mar. Biol. Annu. Rev. 28, 177-276.

Santelices, B., Marquet, P., 1998. Seaweeds, latitudinal diversity patterns, and Rapoport's rule. Divers. Distrib. 4, 71-75.

Saunders, G.W., 2008. A DNA barcode examination of the red algal family Dumontiaceae in Canadian waters reveals substantial cryptic species diversity. Botany 86, 773-789.

Scheffers, B.R., Joppa, L.N., Pimm, S.L., Laurance, W.F., 2012. What we know and don't know about Earth's missing biodiversity. Trends Ecol. Evol. 27, 501510.

Schluter, D., 1996. Ecological causes of adaptive radiation. Am. Nat. 148, S40-S64.

Schluter, D., 2001. Ecology and the origin of species. Trends Ecol. Evol. 16, 372380.

Schultz, N.E., Lane, C.E., Le Gall, L., Gey, D., Bigney, A.R., De Reviers, B., Rousseau, F., Schneider, C.W., 2015. A barcode analysis of the genus Lobophora (Dictyotales, Phaeophyceae) in the western Atlantic Ocean with four novel species and the epitypification of L. variegata (J.V. Lamouroux) E.C. Oliveira. Eur. J. Phycol. 50, 1-20.

Shen, T.-J., Chao, A., Lin, C.-F., 2003. Predicting the number of new species in further taxonomic sampling. Ecology 84, 798-804.

Silberfeld, T., Bittner, L., Fernández-García, C., Cruaud, C., Rousseau, F., Reviers, B., Leliaert, F., Payri, C.E., Clerck, O., 2014. Species diversity, phylogeny and large scale biogeographic patterns of the genus Padina (Phaeophyceae, Dictyotales). J. Phycol. 49, 130-142.

Silberfeld, T., Leigh, J.W., Verbruggen, H., Cruaud, C., De Reviers, B., Rousseau, F., 2010. A multi-locus time-calibrated phylogeny of the brown algae (Heterokonta, Ochrophyta, Phaeophyceae): investigating the evolutionary nature of the "brown algal crown radiation". Mol. Phylogen. Evol. 56, 659674.

Spalding, M.D., Fox, H.E., Allen, G.R., Davidson, N., Ferdaña, Z.A., Finlayson, M., Halpern, B.S., Jorge, M.A., Lombana, A., Lourie, S.A., 2007. Marine ecoregions of the world: a bioregionalization of coastal and shelf areas. Bioscience 57, 573-583.

Stamatakis, A., 2006. RAxML-VI-HPC: maximum likelihood-based phylogenetic analyses with thousands of taxa and mixed models. Bioinformatics 22, 2688-2690.

Stiller, J.W., Waaland, J.R., 1993. Molecular analysis reveals cryptic diversity in Porphyra (Rhodophyta). J. Phycol. 29, 506-517.

Sun, Z., Hanyuda, T., Lim, P.-E., Tanaka, J., Gurgel, C.F.D., Kawai, H., 2012. Taxonomic revision of the genus Lobophora (Dictyotales, Phaeophyceae) based on morphological evidence and analyses $r b c \mathrm{~L}$ and $\operatorname{cox} 3$ gene sequences. Phycologia 51, 500-512. 
Sweetlove, L., 2011. Number of species on Earth tagged at 8.7 million. Nature News [online].

Tronholm, A., Leliaert, F., Sansón, M., Afonso-Carrillo, J., Tyberghein, L., Verbruggen, H., De Clerck, O., 2012. Contrasting geographical distributions as a result of thermal tolerance and long-distance dispersal in two allegedly widespread tropical brown algae. PLoS One 7, e30813.

Vermeij, G.J., Grosberg, R.K., 2010. The great divergence: when did diversity on land exceed that in the sea? Integr. Comp. Biol. 50, 675-682.

Vieira, C., Camacho, O., Wynne, M.J., Mattio, L., Anderson, R., Bolton, J.J., Sansón, M., D'Hondt, S., Leliaert, F., Fredericq, S., Payri, C., De Clerck, O., 2016. Shedding new light on old algae: matching names and sequences in the brown algal genus Lobophora (Dictyotales, Phaeophyceae). Taxon 65, 689-707.

Vieira, C., D'hondt, S., De Clerck, O., Payri, C.E., 2014. Toward an inordinate fondness for stars, beetles and Lobophora? Species diversity of the genus Lobophora (Dictyotales, Phaeophyceae) in New Caledonia. J. Phycol. 50, 1101-1119.

Vieira, C., Payri, C., De Clerck, O., 2015. Overgrowth and killing of corals by the brown alga Lobophora hederacea (Dictyotales, Phaeophyceae) on healthy reefs in New Caledonia: a new case of the epizoism syndrome. Phycol. Res. 63, 152-153.

Williams, S.T., Duda Jr, T.F., 2008. Did tectonic activity stimulate Oligo-Miocene speciation inthe Indo-West Pacific? Evolution 62, 1618-1634.

Zhang, J., Kapli, P., Pavlidis, P., Stamatakis, A., 2013. A general species delimitation method with applications to phylogenetic placements. Bioinformatics 29, 2869-2876.

Zuccarello, G.C., West, J.A., 2003. Multiple cryptic species: molecular diversity and reproductive isolation in the Bostrychia radicans/B. moritziana complex (Rhodomelaceae, Rhodophyta) with focus on North American isolates. J. Phycol. 39, 948-959. 
Table 1. Number of estimated species and resultant percentage of species discovered. The number of species is estimated with the species-richness estimators (ICE, Chao 2 and Jack 1) and with the extrapolation (mean and lower and upper 95\% confidence interval). The percentage of species discovered based on the number of estimated species and the number of discovered species identified.

\begin{tabular}{|c|c|c|c|c|c|c|}
\hline & \multicolumn{3}{|c|}{ Richness estimators } & \multicolumn{3}{|c|}{ Extrapolation } \\
\hline & ICE & Chao 2 & Jack 1 & $\begin{array}{c}\text { Lower } \\
95 \%\end{array}$ & Mean & Upper $95 \%$ \\
\hline No. of species ${ }^{(1)}$ & 209 & 185 & 179 & 140 & 188 & 235 \\
\hline Low DS $(\%)^{(2)}$ & 47 & 53 & 55 & 70 & 52 & 42 \\
\hline Mean DS $(\%)^{(3)}$ & 52 & 59 & 61 & 78 & 58 & 46 \\
\hline Upper DS (\%) $)^{(3)}$ & 58 & 65 & 68 & 86 & 64 & 51 \\
\hline
\end{tabular}

Table 2. Lobophora species diversity per marine region.

\begin{tabular}{lc}
\hline & Species \# (\%) \\
\hline Tropical & $109(81)$ \\
Temperate & $15(11)$ \\
Tropico-temperate & $10(7)$ \\
\hline Pacific & $102(87)$ \\
Atlantic & $15(10)$ \\
Pacific-Atlantic & $4(3)$ \\
\hline Indo-Australian Archipelago & $60(39)$ \\
Western Indo-Pacific & $36(23)$ \\
Central Pacific & $19(12)$ \\
Eastern Pacific & $4(3)$ \\
Atlantic & $15(10)$ \\
\hline Central Indo-Pacific & $57(31)$ \\
Western Indo-Pacific & $35(19)$ \\
Eastern Indo-Pacific & $19(10)$ \\
Temperate Australasia & $6(3)$ \\
Temperate Northern Pacific & $2(1)$ \\
Tropical Eastern Pacific & $4(2)$ \\
Temperate Southern Africa & $1(1)$ \\
Tropical Atlantic & $14(8)$ \\
Temperate Northern Atlantic & $7(4)$ \\
\hline
\end{tabular}

Table 3. Comparison of the fit of the dispersal-extinction-cladogenesis (DEC), dispersal-vicariance analysis (DIVA) and BayArea biogeographical reconstruction models, all with the possibility of founder-event speciation $\left('+\mathrm{J}^{\prime}\right)$. The $\log$-likelihood $(\ln L)$ of each model is given for the analyses. For each geographical subdivision, the best model is indicated in bold. ${ }^{1} 9$ realms: Central Indo-Pacific, Western Indo-Pacific, Eastern Indo-Pacific, Temperate Australasia, Temperate Northern Pacific, Tropical Eastern Pacific, Temperate Southern Africa, Tropical Atlantic, Temperate Northern Atlantic. ${ }^{2} 5$ regions: Indo-Australian Archipelago, Western Indo-Pacific, Central Pacific, Eastern Pacific, Atlantic. ${ }^{3} 3$ regions: Atlantic, Pacific, Indian Ocean. ${ }^{4} 2$ basins: Atlantic, Indo-Pacific.

\begin{tabular}{|c|c|c|c|c|c|}
\hline & 9 realms $^{1}$ & 5 regions $^{2}$ & 3 regions $^{3}$ & 2 basins ${ }^{4}$ & Temp-Trop \\
\hline DEC & -316.5 & -248.0 & $\begin{array}{ll}-69.8 \\
\end{array}$ & -50.2 & -46.3 \\
\hline $\mathrm{DEC}+\mathrm{J}$ & -298.1 & -219.9 & -63.3 & -46.4 & -46.3 \\
\hline DIVA Like & -324.8 & -248.3 & -64.4 & -46.7 & -51.1 \\
\hline DIVA Like $+\mathrm{J}$ & -309.1 & -226.8 & -62.6 & -45.9 & -51.1 \\
\hline BayArea Like & -339.9 & -280.6 & -97.9 & -72.8 & -53.5 \\
\hline BayArea Like + J & -313.8 & -231.3 & -66.6 & -50.1 & -53.3 \\
\hline
\end{tabular}

Table S1. Outgroups used to root the Lobophora tree brown algal tree with their GenBank accession number. 


\begin{tabular}{lccc}
\hline Canistrocarpus cervicornis & LN871906 & - & LN831806 \\
Choristocarpus tenellus & - & AB899285 & AB899261 \\
Cladostephus spongiosus & - & FN667651 & - \\
Cutleria multifida & LC074884 & AB776782 & AB543588 \\
Desmarestia ligulata & EU681444 & AJ287848 & EU681637 \\
Discosporangium mesarthrocarpum & - & AB252654 & AB899262 \\
Ectocarpus siliculosus & AB526435 & AY307410 & FP102296 \\
Fucus vesiculosus & AY494079 & DQ307680 & DQ307679 \\
Ishige okamurae & FJ427586 & AY372975 & AY528830 \\
Laminaria digitata & AJ344328 & AY372984 & AY528849 \\
Phaeothamnion confervicola & - & AF064746 & HQ710732 \\
Schizocladia schiensis & - & AB085615 & AY528859 \\
Sphacelaria divaricata & - & AJ287889 & AY528855 \\
Syringoderma phinneyi & EU681467 & AJ287868 & AY528858 \\
Undaria pinnatifida & GQ368282 & GQ368325 & GQ368354 \\
\hline
\end{tabular}

836

837 Table S2. Similarity matrix of Lobophora the species composition in 9 marine realms calculated with the 838 Sørensen index.

\begin{tabular}{|c|c|c|c|c|c|c|c|c|c|}
\hline & CIP & WIP & EIP & Tau & TNP & TEP & TSA & TAtl & TNA \\
\hline Central Indo-Pacific (CIP) & 1 & - & - & - & - & - & - & - & - \\
\hline Western Indo-Pacific (WIP) & 0.20 & 1 & - & - & - & - & - & - & - \\
\hline Eastern Indo-Pacific (EIP) & 0.16 & 0.04 & 1 & - & - & - & - & - & - \\
\hline Temperate Australasia (TAu) & 0.13 & 0.05 & 0.08 & 1 & - & - & - & - & - \\
\hline Temperate Northern Pacific (TNP) & 0.03 & 0.00 & 0.10 & 0.00 & 1 & - & - & - & - \\
\hline Tropical Eastern Pacific (TEP) & 0.00 & 0.00 & 0.00 & 0.00 & 0.33 & 1 & - & - & - \\
\hline Temperate Southern Africa (TSA) & 0.00 & 0.06 & 0.00 & 0.00 & 0.00 & 0.00 & 1 & - & - \\
\hline Tropical Atlantic (TAtl) & 0.03 & 0.04 & 0.06 & 0.00 & 0.00 & 0.2 & 0.00 & 1 & - \\
\hline Temperate Northern Atlantic (TNA) & 0.03 & 0.05 & 0.08 & 0.00 & 0.00 & 0.18 & 0.25 & 0.92 & 1 \\
\hline
\end{tabular}


841 Figure 1 (A) Lobophora global distribution range based on DNA confirmed samples

842 (black circles) and literature records (white circles). Pictures of (B) L. undulata

843 thallus, (C) L. rosacea growing at the basis of branching Acropora corals in New

844 Caledonia, (D) L. obscura growing on dead corals in New Caledonia, and (E) L.

845 canariensis growing on bedrock in the Canary Islands.

846 Figure 2 Results of the three species delimitation methods based on the cox 3 data set.

847 Species delimitation results of GMYC (inner), ABGD (middle), and PTP (outer) are 848 represented by three concentric circles. The tree is the maximum clade credibility tree $\$ 49$ obtained from BEAST. Only the terminal part of the tree, used for species delineation, 850 is represented. In the center, a Venn diagram illustrating overlap (consensus) between 851 the PTP, GMYC and ABGD species delimitation results.

852 Figure 3 Observed richness ( $\mathrm{S}_{\mathrm{obs}}$ ) in Lobophora species. (A) Comparison between 853 four marine regions: Indo-Pacific (square), Atlantic (triangle), Temperate Australasia 854 (circle), Tropical Eastern Pacific (diamond). (B) Comparison between multiple spatial 855 scales: local (New Caledonia, diamond), sub-regional (Central Indo-Pacific, circle), 856 regional (Indo-Pacific, triangle), and global (square).

857 Figure 4 Chronogram resulting from the Bayesian relaxed clock analysis with 858 BEAST 1.8.2. The purple bars display the 95\% HDP (highest probability density). 859 Lineage-through-time (LTT) plot of Lobophora based on the chronogram presented in 860 Fig. 4, with the $95 \%$ confidence intervals. The red vertical lines display the 861 emergence of major marine barriers: Terminal Tethyan event (ca. -18 Ma), the 862 Isthmus of Panama (ca. 3 Ma), Benguela upwelling formation (ca. 1-2 Ma). The blue 863 line displays sea-level variation based on Miller et al. (2005). 
864 Figure 5 Ancestral ranges of Lobophora species, estimated under a DEC+J model 865 with BioGeoBears based on the BEAST tree (Fig. 4). Boxes at the tips indicate extant 866 Lobophora species geographic area(s). Colored branches indicate regions of maximal 867 probability. Ancestral area reconstructions are shown by pie diagrams at each node. 868 World map (inset lower left) shows the 5 marine realms: Central Indo-Pacific (A), 869 Western Indo-Pacific (B), Eastern Indo-Pacific (C), Tropical Eastern Pacific (D), 870 Atlantic (E). World map (inset middle left) depicts Late Cretaceous continental $\$ 71$ configuration with the hypothetical center of origin of Lobophora (ABE).

872 Figure 6 Sympatry and founder events across the five marine realms. The five marine 873 realms are represented by anotated colored circles: Central Indo-Pacific (A), Western 874 Indo-Pacific (B), Eastern Indo-Pacific (C), Tropical Eastern Pacific (D), Atlantic (E). 875 Numbers within squircles indicate the total number of species per realm. Numbers 876 adjacent to the curved arrows indicate the number of founder events from one realm 877 to another. Numbers within circle arrows indicate the number of sympatric events 878 within a realm. Numbers at the intersection between circles represent the number of 879 species shared between these two realms.

880

881 Figure S1 Lobophora species richness estimation by extrapolation of the rarefaction 882 curve with 95\% confidence interval. Continuous black line represents the observed 883 species richness and the black dashed line represents the estimated diversity by 884 extrapolation. The grayed out area represents the $95 \%$ confidence interval. 885

886 Figure S2 Estimated richness based on the non-parametric richness estimator Chao 2 887 in Lobophora species. A. Comparison between four marine regions: Indo-Pacific 888 (square), Atlantic (triangle), Temperate Australasia (circle), Tropical Eastern Pacific 

diamond), sub-regional (Central Indo-Pacific, circle), regional (Indo-Pacific, triangle), and global (square).

893 Figure S3 Lobophora species tree. The tree is the maximum clade credibility tree 894 obtained from a BEAST analysis of the concatenated alignment of three genes $(r b c \mathrm{~L}$, $895 \operatorname{cox3}$ and $p s b \mathrm{~A})$. The colored hemispheres shown at each node represent Bayesian 896 posterior probabilities (left part of the circle) and ML bootstrap values (right part of 897 the circle) respectively. High support (posterior probabilities $>0.95$ and bootstrap 898 values $>0.9$ ) is indicated in black, while low support (posterior probabilities $<0.95$ 899 and bootstrap values <0.9) is indicated in gray. No color indicates configuration 900 incongruence between the Bayesian and the maximum likelihood trees.

901 Figure S4 The geographic locations of sister species belonging to the Lobophora 902 obscura complex (each branch was identified as a unique species). The phylogenetic 903 relationships between the species are given by the phylogenetic tree resulting from the 904 Bayesian Inference analysis.

905 Figure S5 Relative contribution of vicariance, sympatry and founder events to 906 Lobophora diversity at the marine realms level. The number of species per region are 907 given above each bar. 


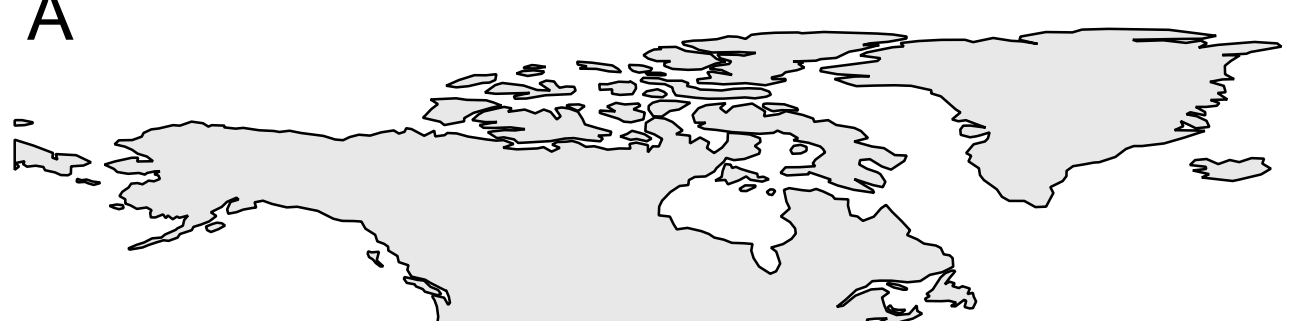

$\because$
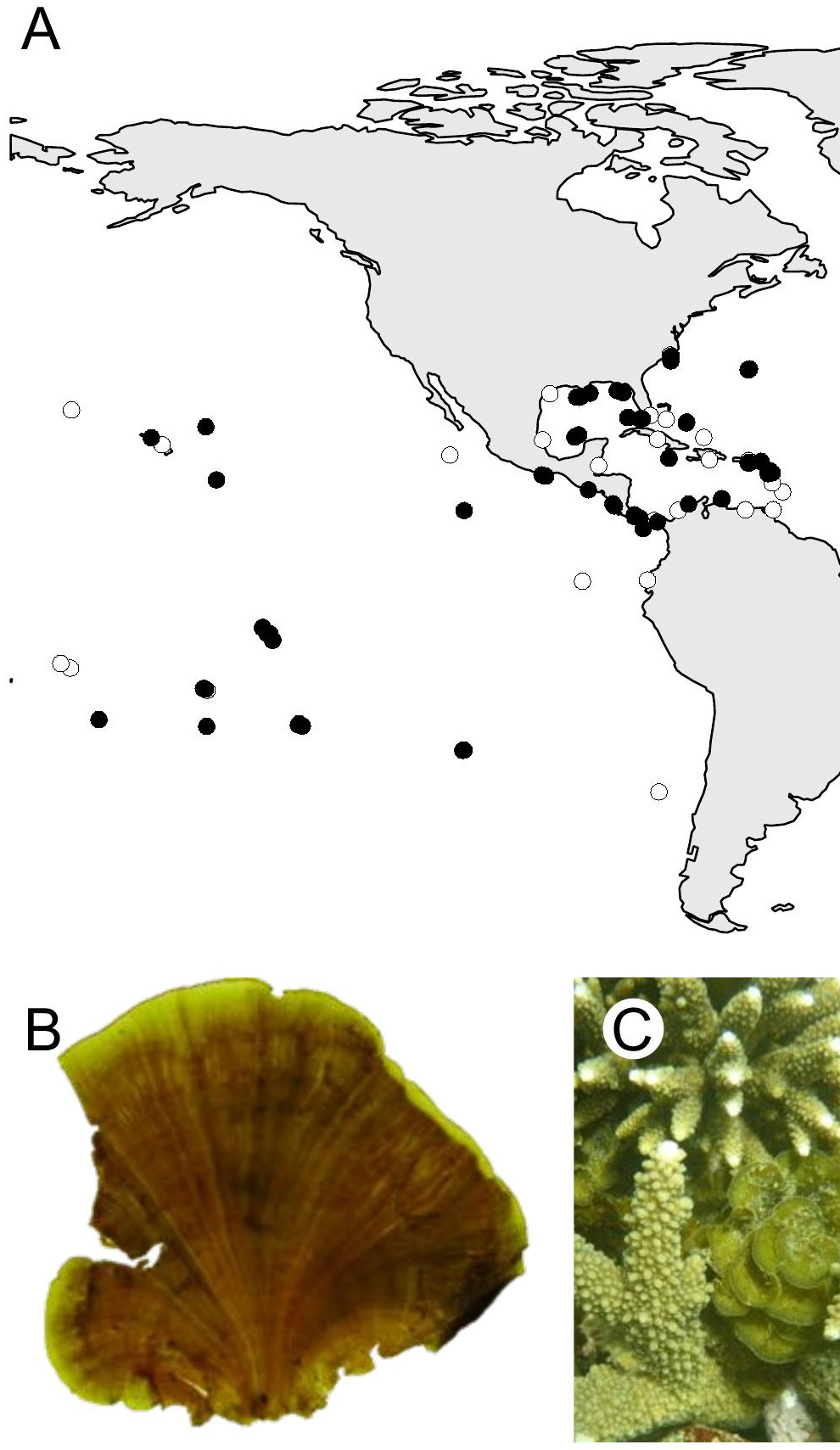

2.

-
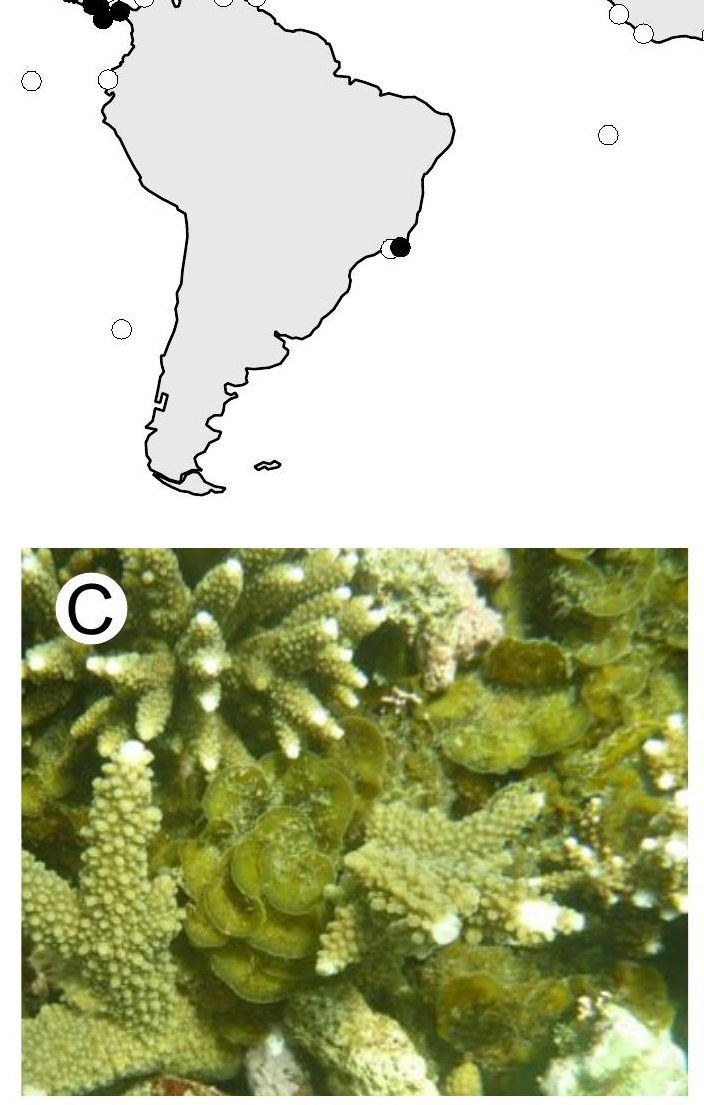

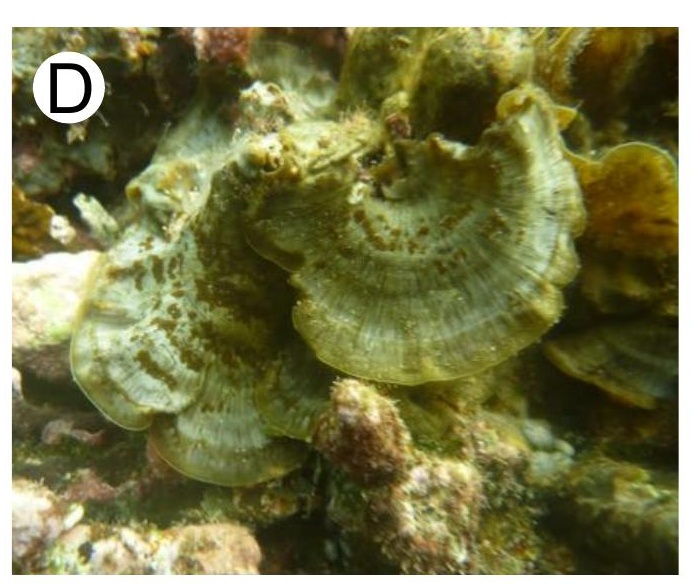

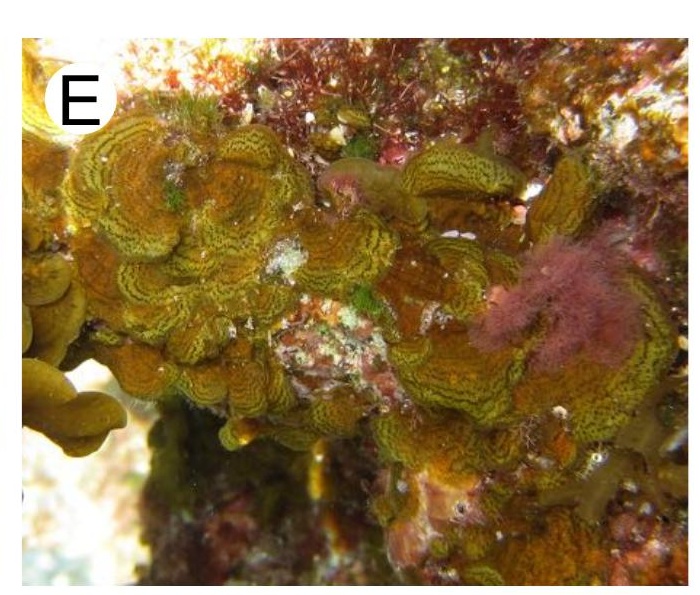
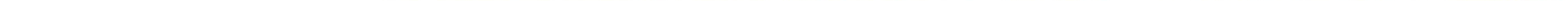






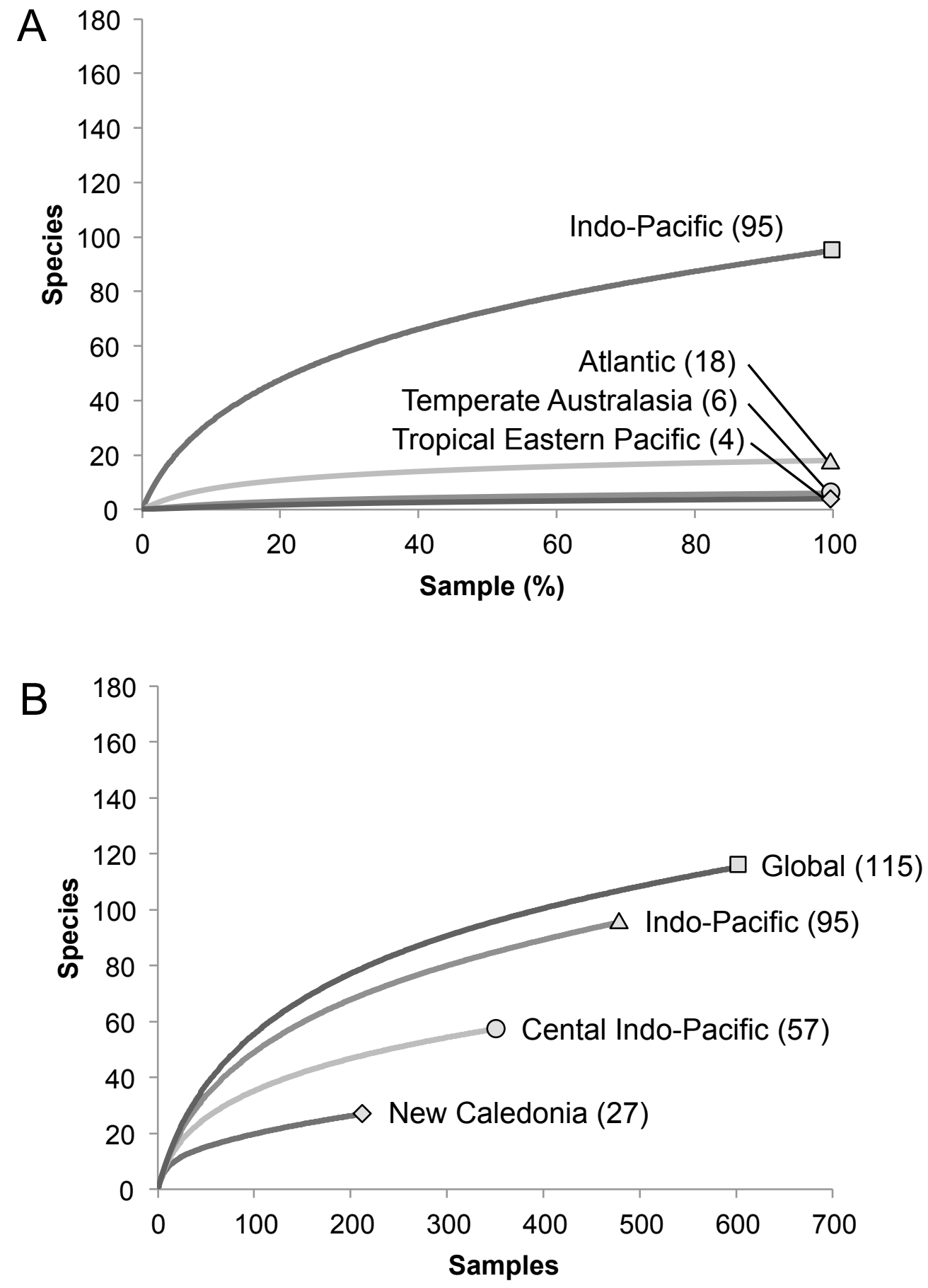


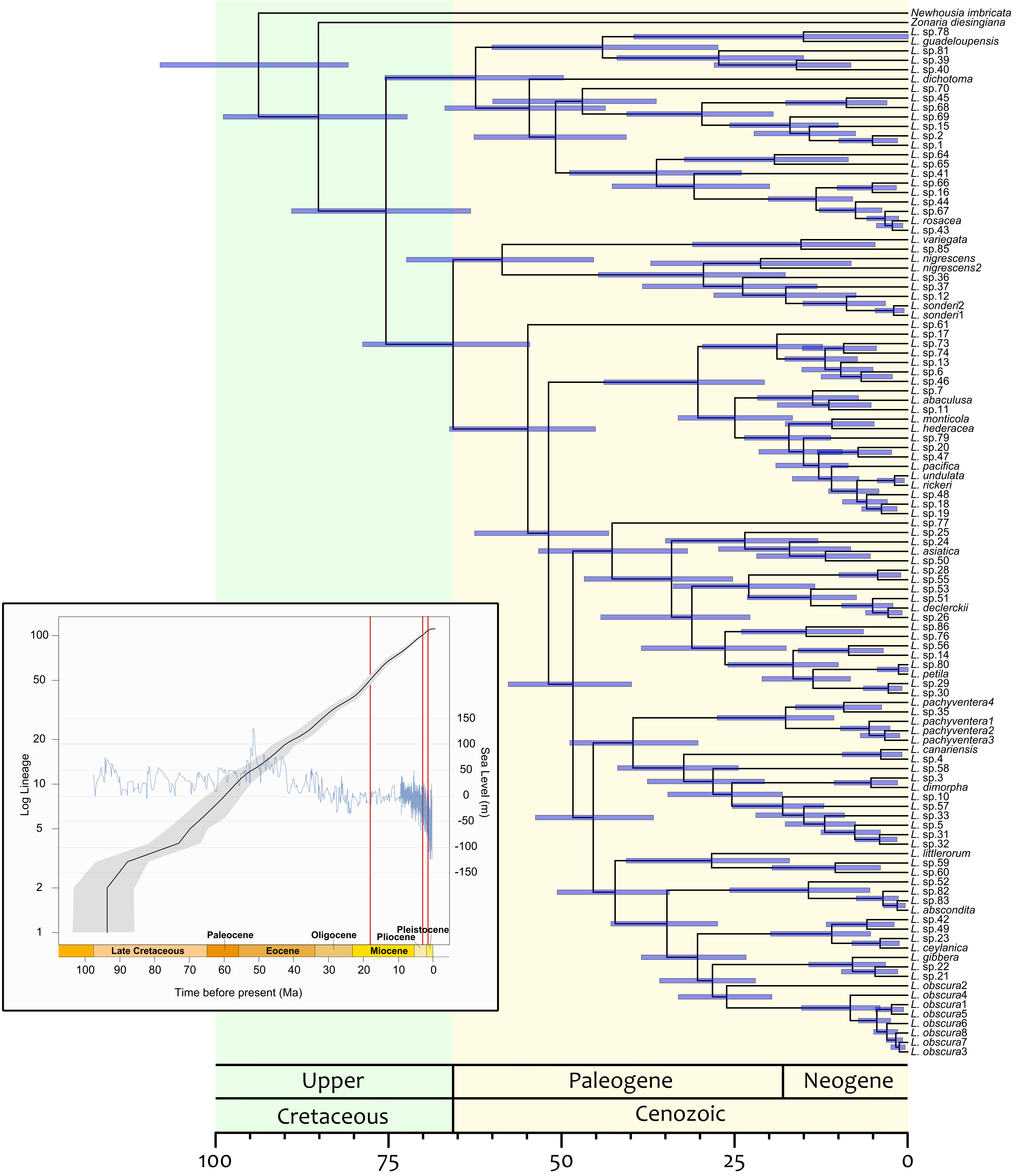




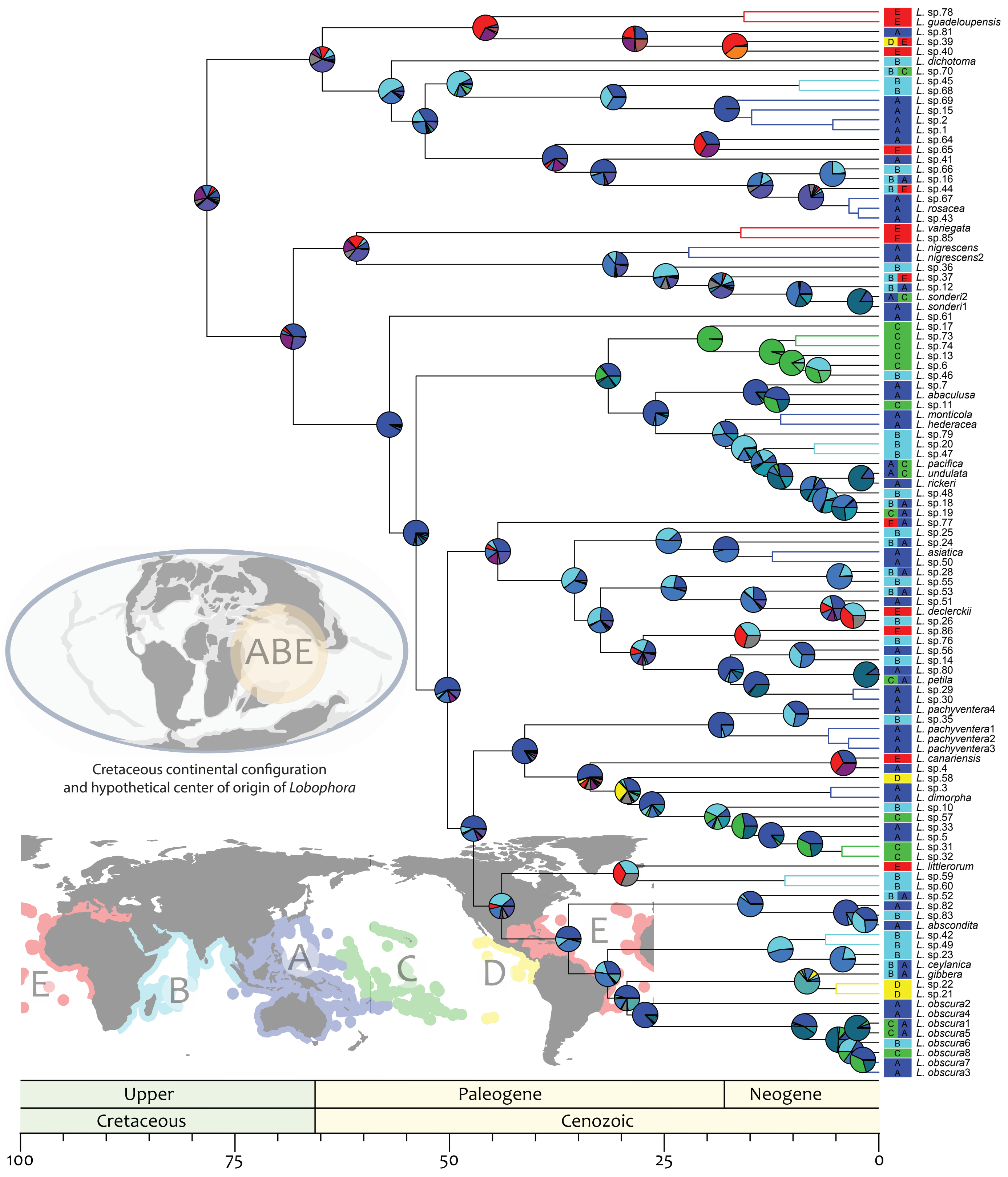




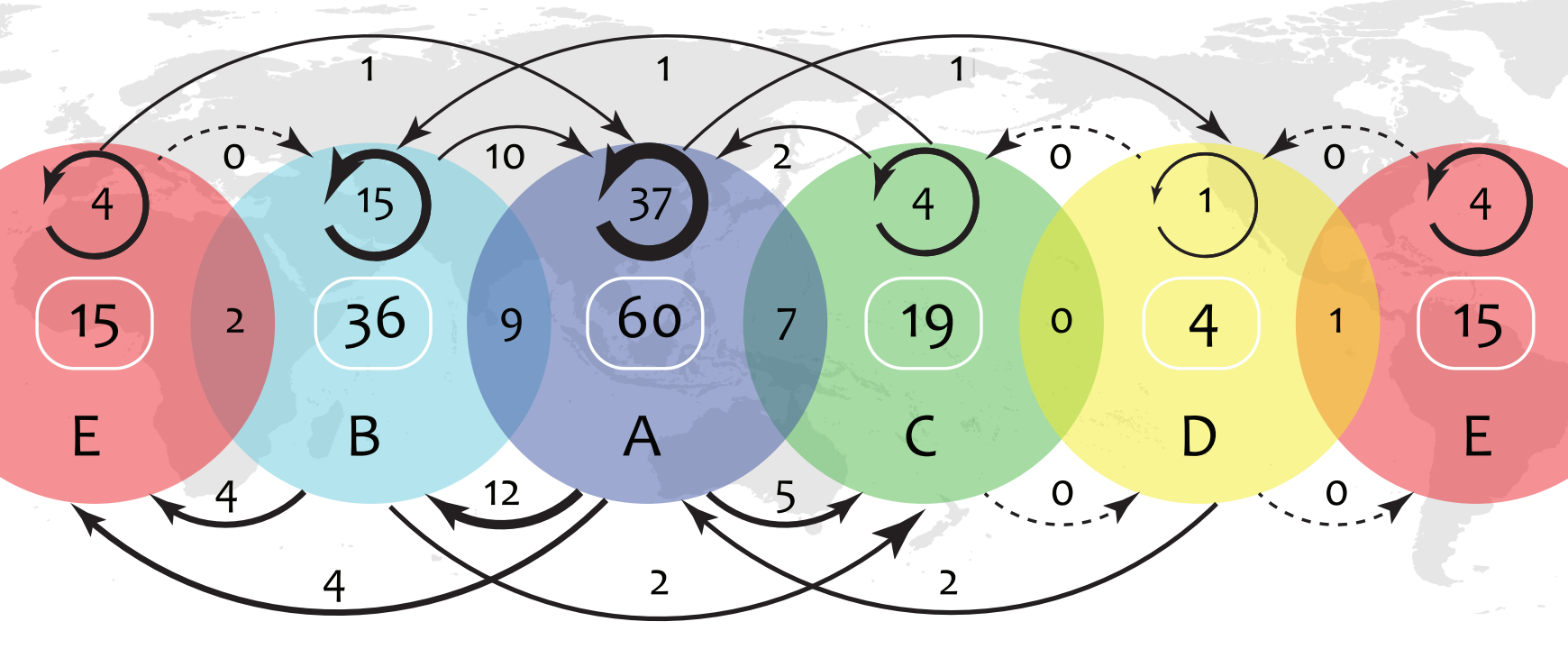




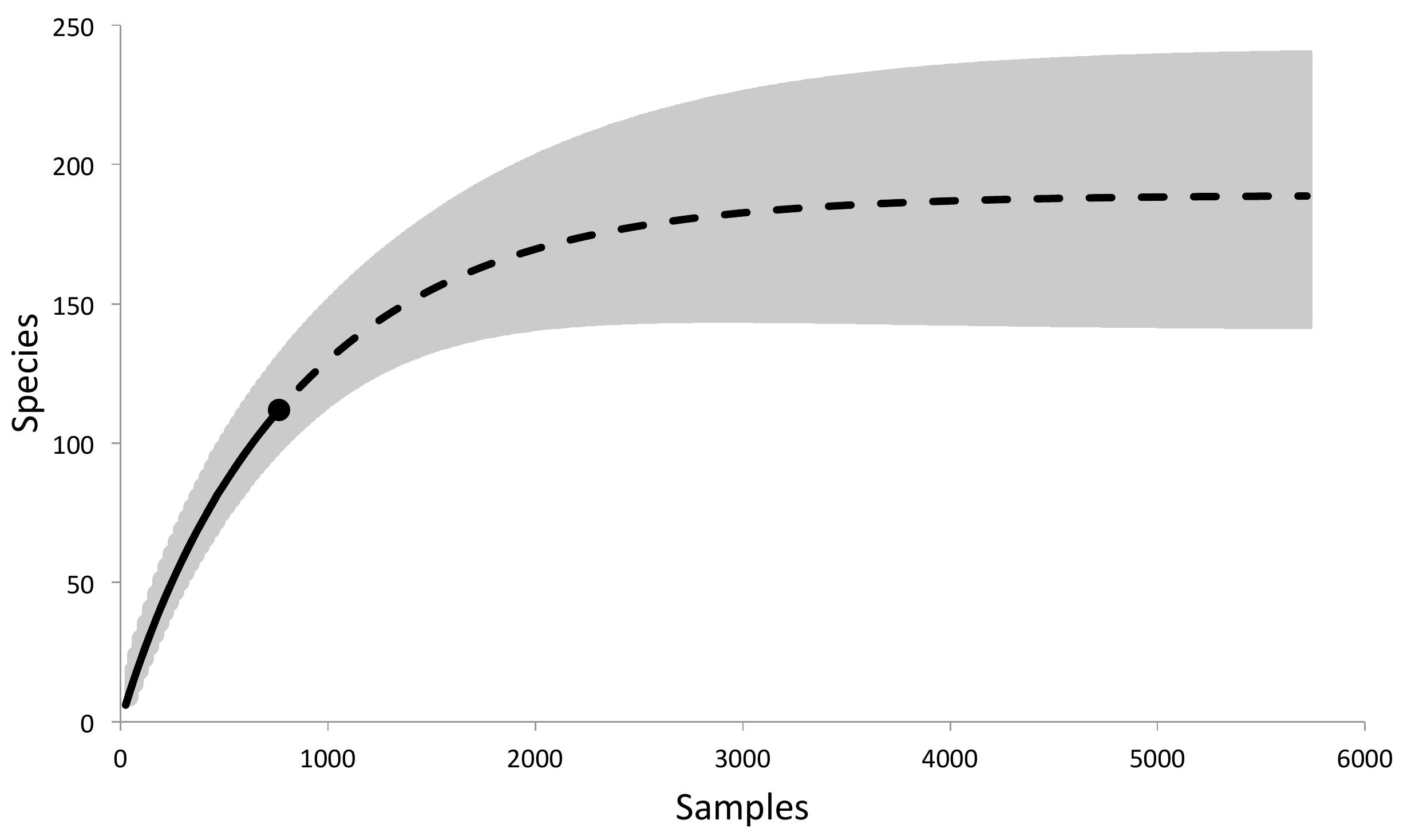



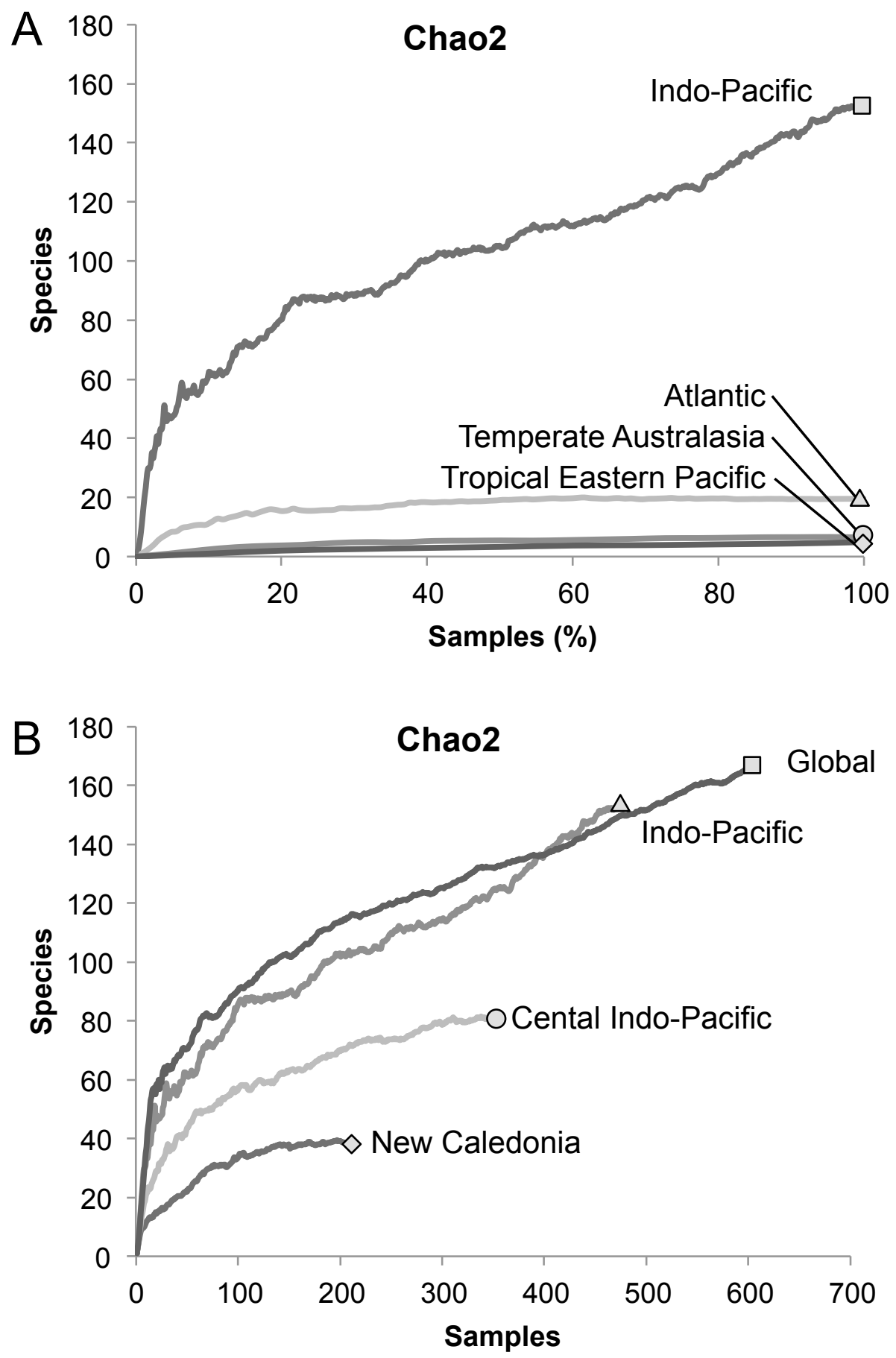


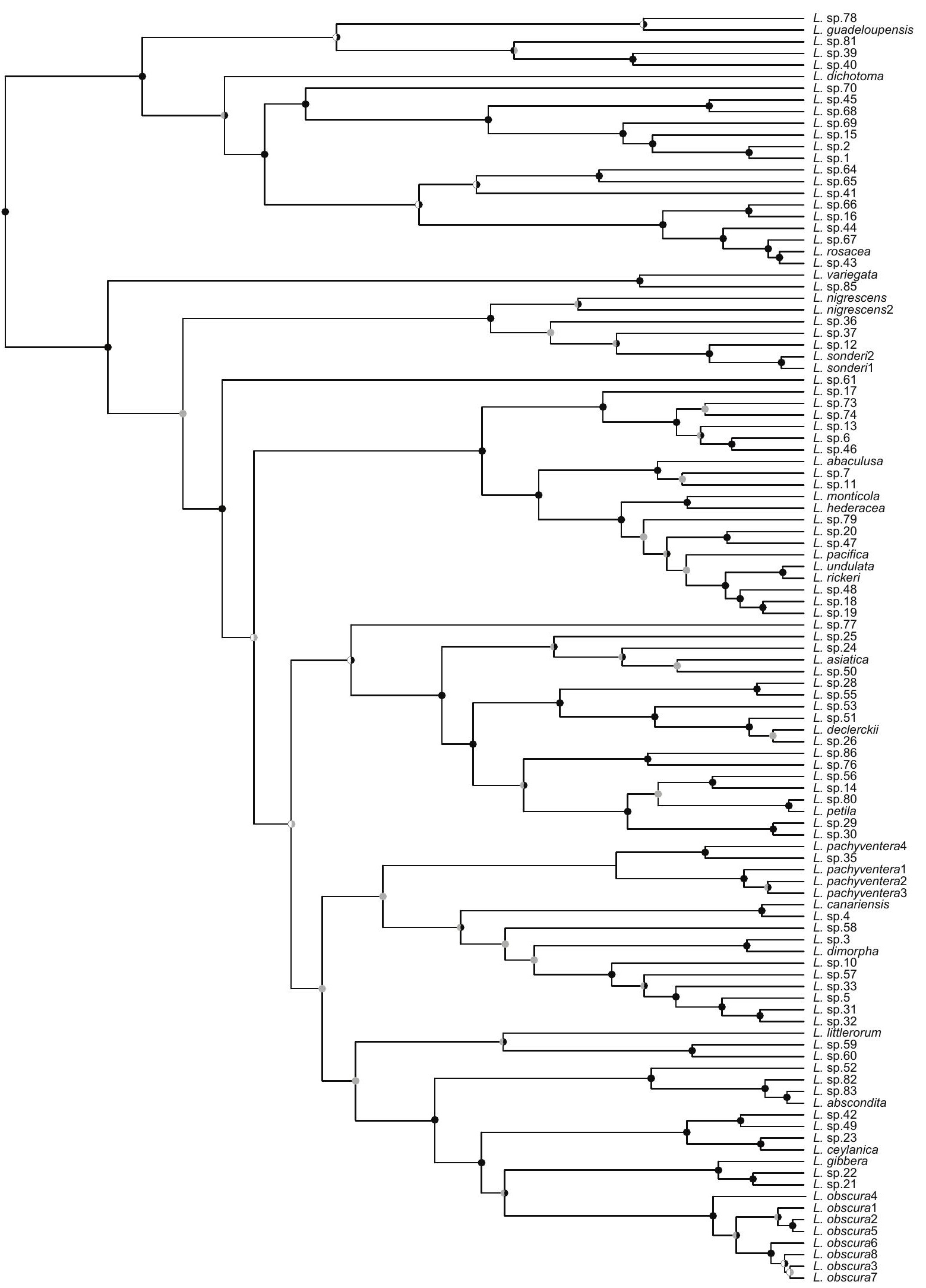




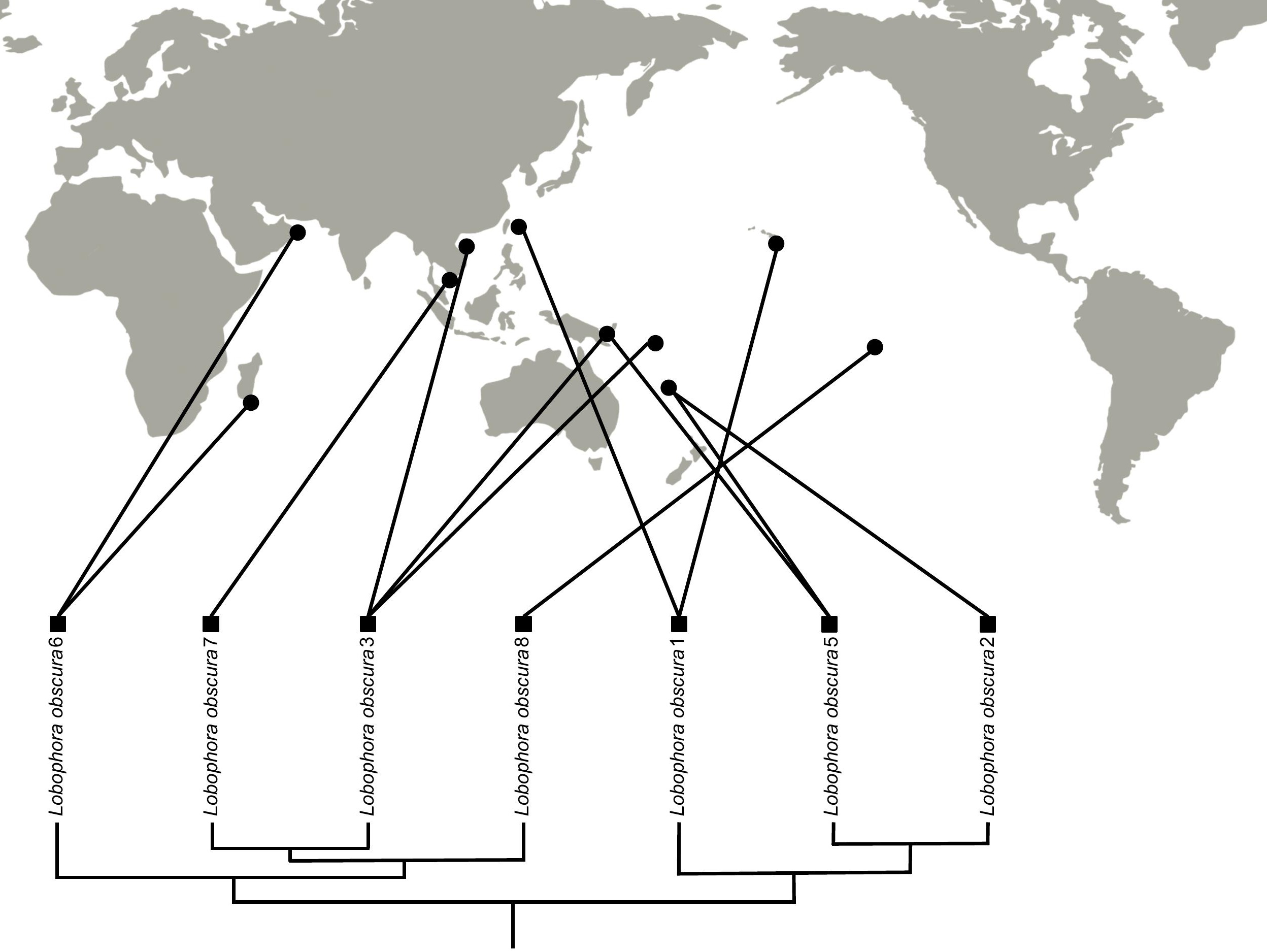


Number of species per region

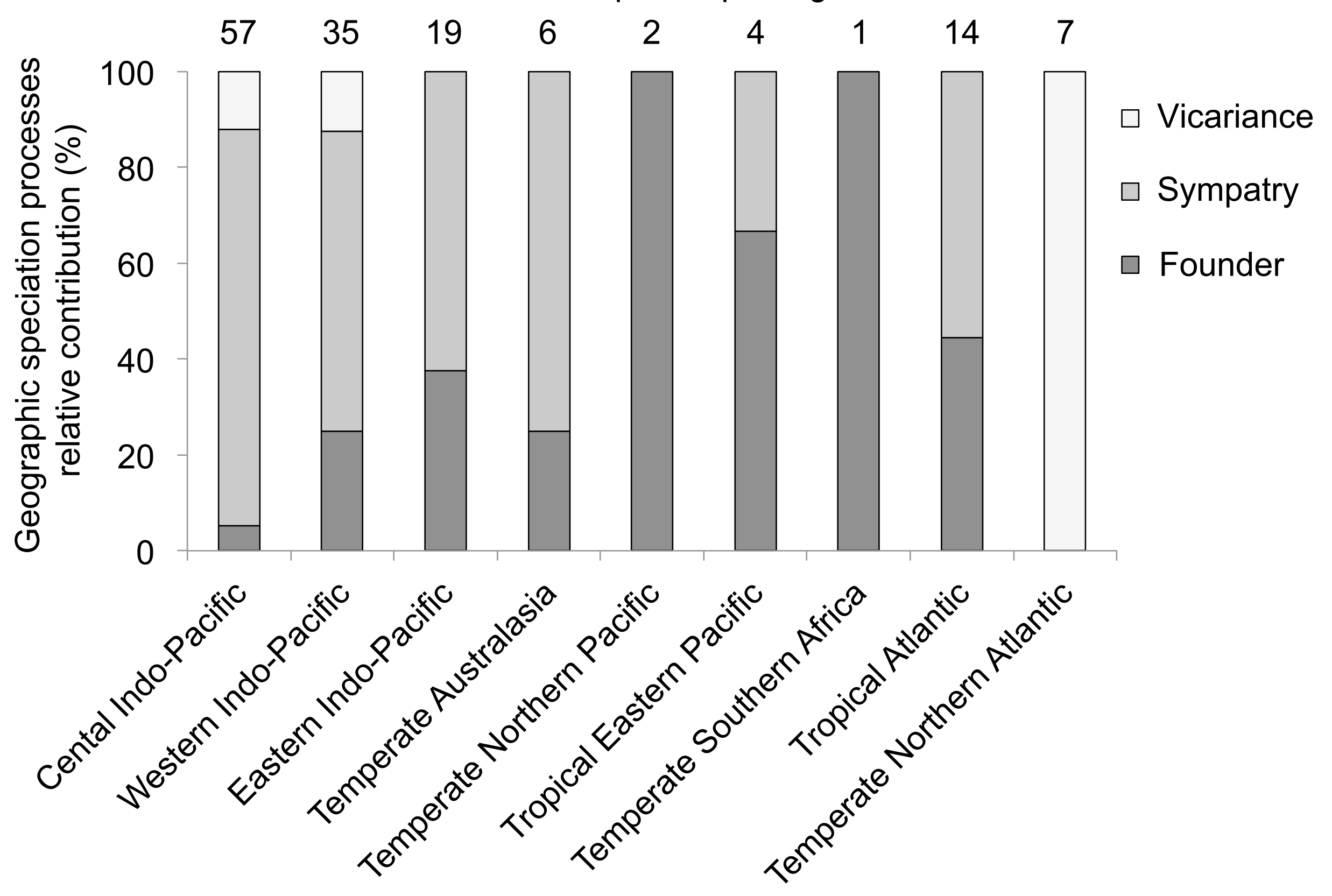

